\author{
Instytut Archeologii \\ Uniwersytetu Mikotaja Kopernika \\ w Toruniu
}

Instytut Ukrainoznawstwa

Narodowej Akademii Nauk

we Lwowie

Krzysztof Cyrek, Oleksandr Sytnyk

\title{
GRAWECKIE STANOWISKO W HALICZU (HALYCU) NA UKRAINIE. WYNIKI POLSKO-UKRAIŃSKICH BADAŃ WYKOPALISKOWYCH
}

Zarys treści. Artykuł omawia wyniki polsko-ukraińskich badań prowadzonych w latach 2000 2004 na stanowisku kultury graweckiej w Haliczu, położonym na wysokiej, lessowej terasie Dniestru. W jego obrębie odkryto koncentrację około 800 fragmentów kości mamuta oraz inwentarz składający się z ponad 6000 wyrobów krzemiennych zlokalizowanych w sąsiedztwie dwóch palenisk. Na podstawie analiz termoluminescencyjnych i radiowęglowych wyznaczono trzy fazy zasiedlenia tego miejsca datowane od 25 do 19 tysięcy lat p.n.e.

\section{Historia badań}

Paleolityczne stanowisko w Haliczu I (IB w numeracji odsłonięć geologicznych) zostało odkryte w 1988 roku przez M. Bandrovskiego. W 1997 roku badania sondażowe przeprowadził tu lwowski badacz paleolitu, O. Sytnyk. W latach 2000-2004 natomiast stanowisko objęto systematycznymi pracami wykopaliskowymi w ramach polsko-ukraińskiej ekspedycji; kierowali nimi K. Cyrek i O. Sytnyk (Cyrek, Sytnyk 2002, s. 293-314). Projekt ten był zasadniczym elementem umowy o naukowej współpracy między Instytutem Archeologii i Etnologii Uniwersytetu Mikołaja Kopernika a Instytutem Ukrainoznawstwa Narodowej Akademii Nauk we Lwowie. Współpraca rozpoczęła się w 1997 roku, kiedy autor niniejszego artykułu został zaproszony do udziału w sympozjum poświęconym stratygrafii lessów wschodniego i zachodniego Podkarpacia. Zaowocowało to w 1999 roku Jego udziałem wraz z grupą toruńskich studentów w badaniach wykopaliskowych prowadzonych przez O. Sytnyka na środkowopaleolitycznym stanowisku w Jezupolu. Rok później, latem 2000 roku, rozpoczęto wspólne badania w Haliczu; były one 
realizowane w ramach szerszego programu badawczego dotyczącego stratygrafii i paleolitu wschodniego Podkarpacia i Podola. W skład interdyscyplinarnego zespołu, oprócz archeologów, weszli również przyrodnicy T. Madeyska, A. Bogucki, M. Łanczont, A. Jacyszyn, P. Wojtal, W. P. Aleksandrowicz, R. Dmitruk, M. Komar, H. Hercman, P. Gorka i J. Kusiak - reprezentujący placówki naukowe z Kijowa, Lwowa, Krakowa, Lublina i Warszawy.

Wyniki dotychczasowych badań były kilkakrotnie publikowane (Sytnyk, Bogucki, Łanczont 1999, s. 15-21; Wojtal, Cyrek, Sytnyk 2001, s. 137-142; Cyrek i in. 2002, s. 97-109; Cyrek, Sytnyk 2002, s. 293-314; Sytnyk i in. 2004, s. 215-237; Sytnyk i in. 2005, s. 32-89; Cyrek i in. 2005, s. 17-28; Łanczont i in. 2005, s. 3-15). Powstało też zbiorowe interdyscyplinarne opracowanie pt. „Lessy i paleolit Naddniestrza Halickiego (Ukraina)” pod redakcją T. Madeyskiej (Lessy i paleolit 2002). W monografii tej dla rekonstrukcji środowiska Naddniestrza (w tym również okolic stanowiska w Haliczu) wykorzystano wyniki analiz malakologicznych, palinologicznych, mikromorfologicznych i paleozoologicznych; ponadto uziarnienia sedymentów, zawartości w nich próchnicy, węglanu wapnia, trójtlenku żelaza i minerałów ciężkich. Do datowania wykorzystano metodę paleomagnetyczną, termoluminescencyjną, radiowęglową i uranowo-torową.

\section{Położenie i charakterystyka przyrodniczych walorów stanowiska}

Pod względem fizjograficznym Naddniestrze Halickie stanowi fragment Wschodniego Podkarpacia; od północy graniczy z Wyżyną Podolską (ryc. 1). Stanowisko Halicz I znajduje się na północnym cyplu Wyżyny Przyłukwińskiej, a jednocześnie na południowo-wschodnim skraju Kotliny Halicko-Bukaczewskiej. Ponadto jest to granica dwóch prowincji: Podkarpacia po prawej stronie doliny Dniestru i Równiny Wschodnioeuropejskiej po lewej stronie rzeki, co w górnym plejstocenie skutkowało przede wszystkim przejściowym charakterem kilku elementów środowiska - krajobrazu, klimatu, fauny i flory.

Górne Naddniestrze jest jednym z najbogatszych pod względem liczby stanowisk, obszarów paleolitycznej ekumeny środkowowschodniej Europy (Czernysz 1959; Cyrek, Sytnyk 2002, s. 293-314). W dużym stopniu decydowały o tym korzystne warunki ówczesnego stepowego krajobrazu, do których należała urozmaicona rzeźba powierzchni ziemi, bogata sieć rzeczna z szerokimi, a jednocześnie głęboko wciętymi, dolinami czy złoża wysokiej jakości surowca krzemiennego. Istotną rolę w kształtowaniu klimatu miało 
sąsiedztwo Karpat, które stanowiły wówczas naturalną barierę pomiędzy środkowo- i wschodnioeuropejskimi centrami paleolitycznych kultur.

Znaczenie stanowiska w Haliczu wynika w dużej mierze z jego lokalizacji w obrębie jednej z najdłuższych w tym rejonie lessowych sekwencji stratygraficznych z reliktami plejstoceńskich gleb kopalnych (Łanczont i in 2002). Zadokumentowano tu 50-metrowy profil środkowo- i górnoplejstoceńskich sedymentów (stanowisko IB) z zachowaną górnopaleolityczną warstwą kulturową (ryc. 2).

Stanowisko w Haliczu znajduje się na cyplu wysokiej V terasy prawego brzegu Dniestru, wznoszącej się 285-290 m n.p.m. Silna ekspozycja tego miejsca - wynosząca dzisiaj około $40 \mathrm{~m}$ nad terasą zalewową - otoczonego dolinami Dniestru, Łukwy i bezimiennego potoku, prawdopodobnie stanowiła o jego osadniczej atrakcyjności dla paleolitycznych łowców (ryc. 3). Istotnym walorem mogła być również obecność otoczaków kredowego krzemienia turońskiego (naddniestrzańskiego) w aluwiach wspomnianych rzek. Bardzo ważną okolicznością dla paleolitycznego osadnictwa był, zapewne łagodniejszy niż na przeważającej części Podola, klimat; świadczy o tym fauna ślimaków (Aleksandrowicz i in. 2002, s. 287-288) oraz brak silnie rozwiniętych struktur mrozowych w lessowych utworach doliny Dniestru (Łanczont i in. 2002, s. 25, 26).

Analizie malakologicznej poddano próby lessu pobrane z fragmentu profilu stanowiska, między górnoplejstoceńskimi glebami Rivne i Dubno, w tym również z warstwy kulturowej. Uzyskano w ten sposób 288 okazów mięczaków, wśród których rozpoznano 13 gatunków. Charakterystyczną cechą uzyskanej malakofauny jest duży udział gatunków związanych ze stosunkowo wilgotnymi siedliskami o znacznym zaciemnieniu, przy niewielkim udziale tych, które zajmowały siedliska otwarte i dominacji form mezofilnych (Aleksandrowicz i in. 2002, s. 262, ryc. 65; tab. 29). Taki zespół mięczaków wskazuje na złagodzenie klimatu i obecność zacienionych i wilgotnych miejsc, które zdają się świadczyć o lokalnych warunkach dogodnych również dla ludzkiego osadnictwa. Podczas próby przeprowadzenia analizy pyłkowej, na skutek znacznego stopnia zniszczenia materiału zawartego w próbach pobranych z warstwy kulturowej, uzyskano jedynie pojedyncze ziarna, które można było zidentyfikować co do rodzaju i rodziny, bez możliwości sformułowania wiarygodnych wniosków (Komar 2002, s. 250, 251).

W ciągu czterech sezonów prac wykopaliskowych przebadano zwarty obszar o powierzchni $340 \mathrm{~m}^{2}$ (ryc. 4). Na podstawie pobieżnej analizy morfologii terenu oraz wykopów sondażowych, można przypuszczać, że całkowita 


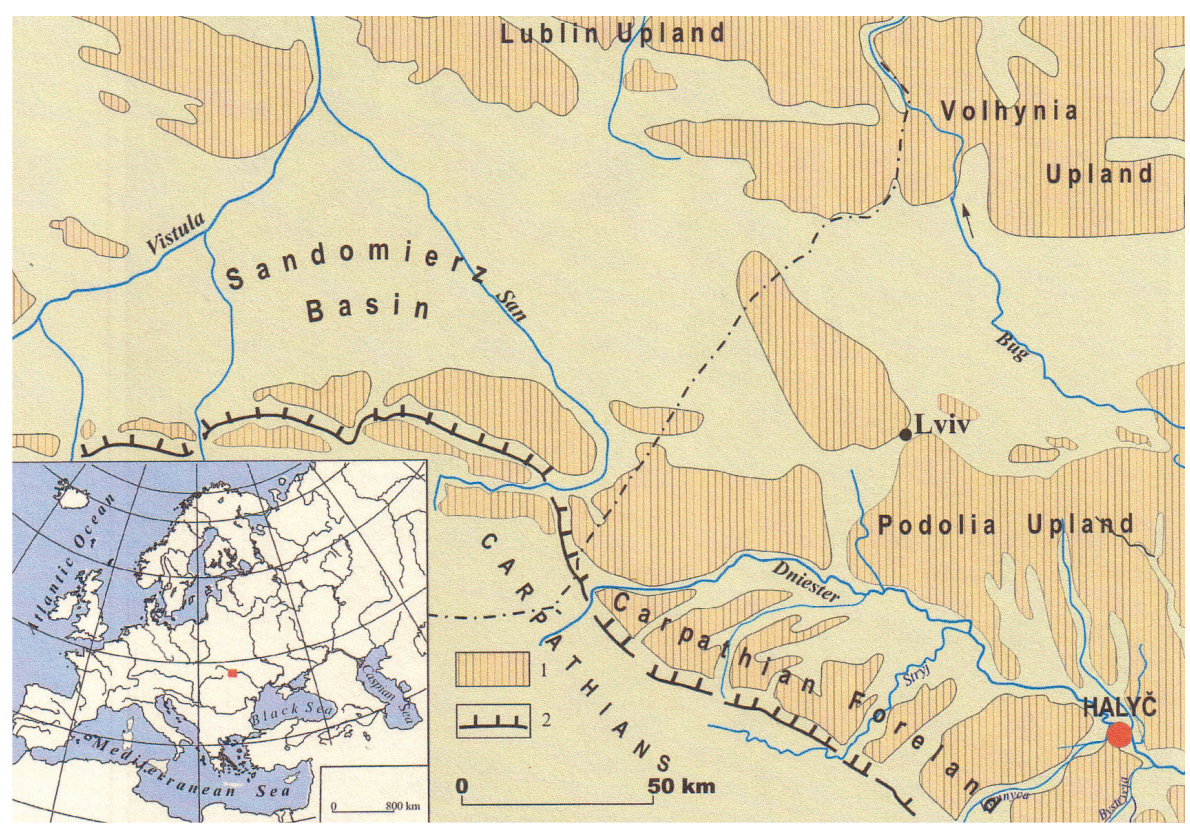

Ryc. 1. Geograficzne położenie stanowiska I w Haliczu. 1 - zasięg występowania lessów, 2 - granica Karpat (wg Łanczont i in. 2005; rys. O. Sytnyk)

Fig. 1. Geographical location of site I in Halych. 1 - the range of loess occurrence, 2 - the border of the Carpathians (after Łanczont et al 2005; drawing by O. Sytnyk)

powierzchnia stanowiska wynosi co najmniej $1000 \mathrm{~m}^{2}$. Spora jego część została zniszczona przez przemysłową eksploatację lessu na potrzeby miejscowej, nieczynnej już, cegielni. Właśnie osuwające się ściany wyrobiska ujawniły obecność paleolitycznej warstwy kulturowej. Wykopy badawcze (I-IVa) były usytuowane na krawędzi wyrobiska, z wyjątkiem sondażowego wykopu $\mathrm{V}$, w którym zadokumentowano obecność warstwy kulturowej na kulminacji cypla. Tak duży obszar potencjalnego występowania paleolitycznych znalezisk spowodował konieczność wyznaczenia miejsc, gdzie należałoby w przyszłości wytyczyć kolejne wykopy badawcze. Dlatego w 2004 roku podjęto próbę szacunkowego określenia struktury stanowiska za pomocą badań geofizycznych, metodą magnetyczną, elektromagnetyczną i elektrooporową ; objęto nimi obszar $25 \times 50 \mathrm{~m}$, na którym spodziewano się pozostałości górnopaleolitycznego osadnictwa. Wykonano kilka tysięcy pomiarów, co umożliwiło wykreślenie map anomalii magnetycznych oraz profili elektromagnetycznych i elektrooporowych. W miejscach występo-

\footnotetext{
${ }^{1}$ Badania te przeprowadził zespół geofizyków z Uniwersytetu Śląskiego dzięki funduszom Fundacji Nauki Polskiej w ramach programu SUBIN (Lanczont i in. 2005).
} 


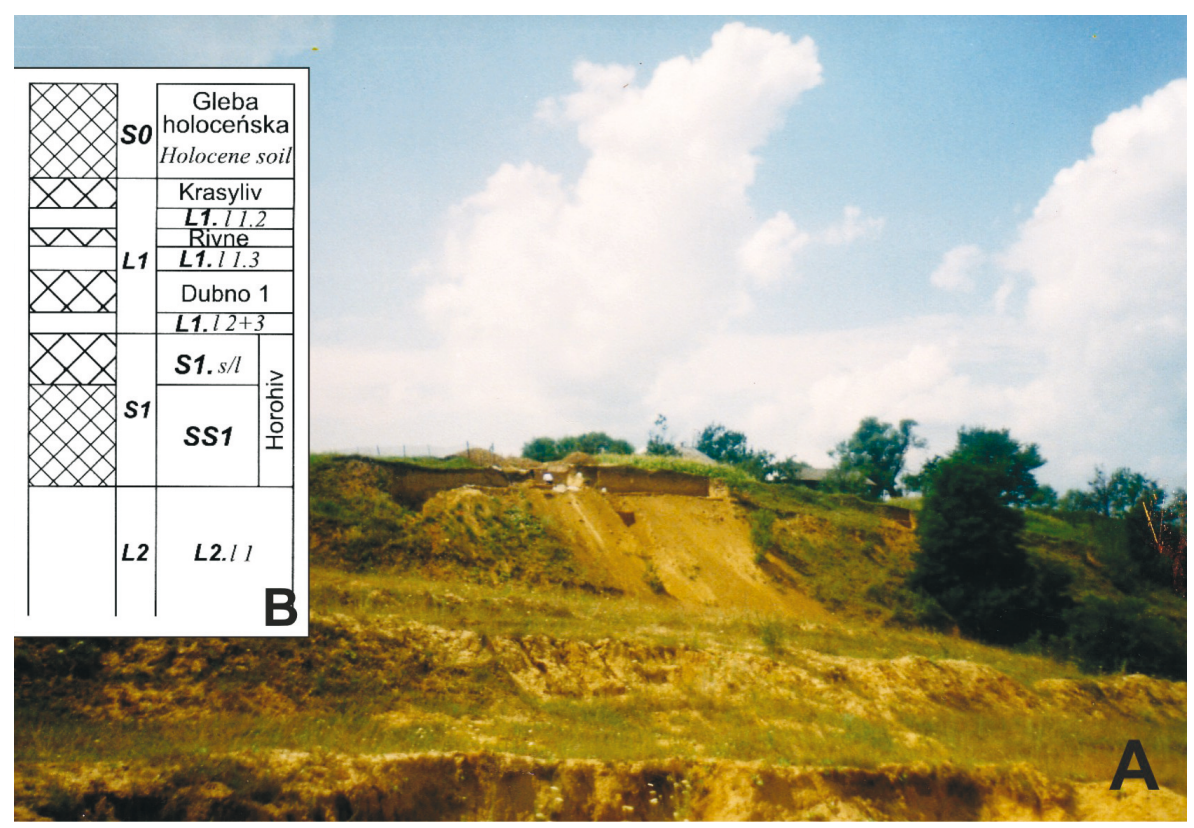

Ryc. 2. A - Halicz, Ukraina, stanowisko I; widok od północy, na pierwszym planie zniszczona część stanowiska. B - Halicz IB, Ukraina; schemat stratygrafii lessów i gleb kopalnych: SO - współczesna gleba; L1. 1 1, 2, 3 - lessy i gleby vistuliańskie (Krasyliv, Rivne, Dubno); S1. s/1, SS1 - kompleks gleb kopalnych typu Horohiv (interglacjał eemski); L2. 11 - lessy warciańskie (fot. K Cyrek; rys. O. Sytnyk)

Fig. 2. A-Halych, Ukraine, site I; view from the north, in the foreground- a damaged part of the site. B - Halych IB, Ukraine; schematic diagram of loess and fossil soils stratigraphy: SO - modern soil; L1. 11, 2, 3 - loess and Vistulian soils (Krasyliv, Rivne, Dubno); S1. s/1, SS1 - fossil soils of Horohiv type (eemian interglacial); L2. 11 - loess from the Warthe (Wosltonian) Stage (phot. by K Cyrek; drawing by O. Sytnyk)

wania anomalii geofizycznych przeprowadzono ich geologiczną weryfikację polegającą na wykonaniu 13 ręcznych wierceń sondażowych o głębokości od 2,4 do 4,2 m, w których (poza skupiskami węgielków drzewnych) nie natrafiono na ewidentne ślady paleolitycznej warstwy kulturowej. Należy jednak podkreślić małą wiarygodność tego rodzaju weryfikacji, wynikającą z niewielkiej liczby rozproszonych na sporym obszarze i liczących zaledwie po kilka centymetrów średnicy otworów sondażowych. Dlatego w miejscach szczególnie silnych anomalii konieczne będzie w przyszłości założenie wykopów sondażowych. 


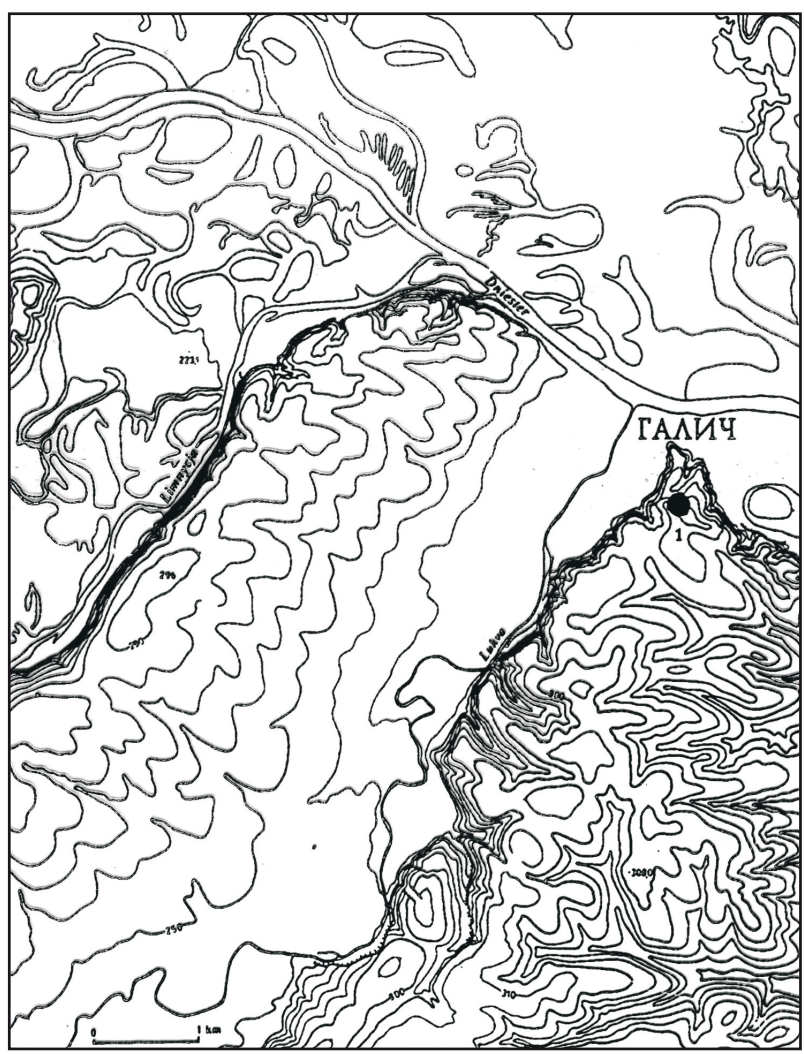

Ryc. 3. Halicz, Ukraina, stanowisko I. Położenie stanowiska na planie hipsometrycznym (rys. O. Sytnyk)

Fig. 3. Halych, Ukraine, site I. Location of the site with a hypsometrical layout (drawing by O. Sytnyk)

\section{Stratygrafia stanowiska}

W obrębie górnoplejstoceńskich lessów budujących górną partię wysokiej V terasy Dniestru zadokumentowano następującą stratygrafię stanowiska archeologicznego (ryc. 5):

- pylasto-piaszczysty less z mikrostrukturami mrozowymi (1),

- współczesna gleba (2) z reliktami II warstwy kulturowej w spagu,

- gleba kopalna typu Rivne (3) zachowana w postaci szaro-rudawej plamistości,

- wyroby krzemienne (4),

- kości zwierzęce (5),

- poziomy organiczne (6) stanowiące relikty I warstwy kulturowej (Ia, Ib, Ic). 


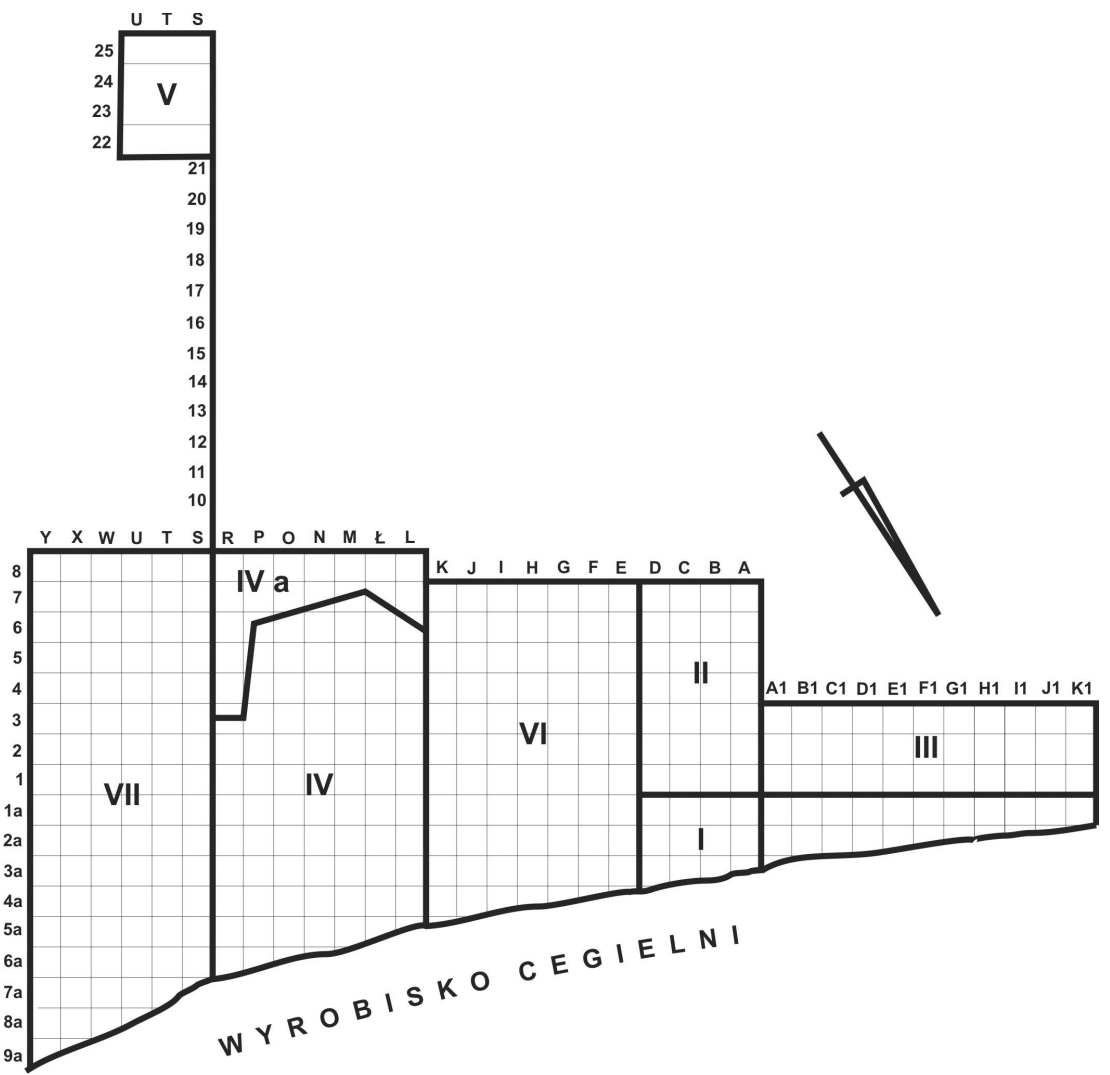

Ryc. 4. Halicz, Ukraina, stanowisko I. Lokalizacja i numeracja wykopów badawczych (rys. M. Sudoł)

Fig. 4. Halych, Ukraine, site I. Location and numbering of excavation trenches (drawing by M. Sudoł)

Warstwa kulturowa II to rozproszone we wszystkich wykopach, pojedyncze wyroby krzemienne; występowały one w strefie o miąższości około $20 \mathrm{~cm}$, na pograniczu poziomów SO (gleba holoceńska) i L1 (górnoplejstoceński less wałdajski) w schemacie stratygrafii lessów Naddniestrza (Boguckyj, Łanczont 2002, s. 94-96, ryc. 24). W sumie było to około 200 pozbawionych patyny i nieretuszowanych okazów, odizolowanych stratygraficznie od znalezisk górnopaleolitycznych. Na przebadanej powierzchni nie natrafiono na żadne inne obiekty związane z tą fazą zasiedlenia. Prawdopodobnie jest to pozostałość późnoplejstoceńskich, krótkotrwałych obozowisk o niemożliwej do określenia schyłkowopaleolitycznej tradycji kulturowej.

Dużo lepiej zachowała się górnopaleolityczna I warstwa kulturowa. Zalegała ona w spagu rowieńskiego poziomu glebowego i bezpośrednio pod nim 


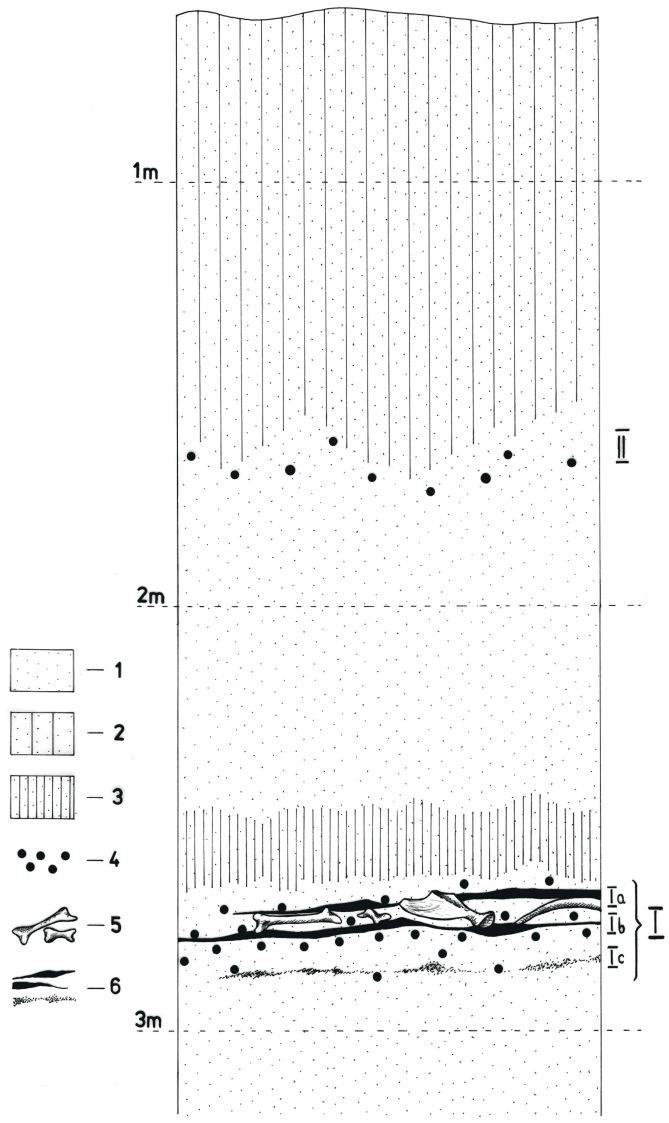

Ryc. 5. Halicz, Ukraina, stanowisko I. Stratygrafia stanowiska: I - dolna, trójdzielna, górnopaleolityczna warstwa kulturowa (Ia - młodsza faza zasiedlenia, Ib - środkowa faza zasiedlenia, Ic - starsza faza zasiedlenia); II - górna, późnopaleolityczna warstwa kulturowa; 1 - less z mikrostrukturami mrozowymi, 2 - gleba holoceńska, 3 - gleba kopalna Rivne, 4 - wyroby krzemienne, 5 - kości, 6 - poziomy organiczne (rys. O. Sytnyk, M. Sudoł)

Fig. 5. Halych, Ukraine, site I. Stratigraphy of the site: I - lower, triple, Upper Palaeolithic cultural layer (Ia - younger phase of inhabitation, Ib - middle phase of inhabitation, Ic - older phase of inhabitation); II - upper Late Palaeolithic cultural layer; 1 - loess with frost microstructures, 2 - Holocene soil, 3 - Rivne - fossil soil, 4 - flint artefacts, 5 - bones, 6 - organic levels (drawing by O. Sytnyk, M. Sudoł)

na głębokości od 265 do $290 \mathrm{~cm}$ od reperu, w warstwie lessu urozmaiconej mikrostrukturami mrozowymi (L1; Bogucki, Łanczont, 2002, s. 94-96, ryc. 24). Na przebadanym obszarze tworzyły ją koncentracje wyrobów krzemiennych, kości zwierzęcych, węgielków drzewnych oraz ochry. W niektórych profilach 
warstwa zachowała się w postaci trzech nieciaggłych ciemnoszarych i czarnych pasemek (Ia, Ib, Ic), każde o kilkucentymetrowej miąższości, rozdzielonych warstewkami jałowego lessu (ryc. 6). Szczególnie intensywnie nasycone węgielkami drzewnymi było górne (Ia) i środkowe (Ib) pasmo. W ich obrębie odkryto dwa okrągłe paleniska (nr 1 i nr 2) o rozmytych w wyniku podepozycyjnych procesów naturalnych (denudacja i kretowiny) konturach (ryc. 7). Prawdopodobnie wspomniane warstewki-pasemka to w dużym stopniu rozmyte przez erozję i rozdeptane przez ludzi oraz zwierzęta, paleniska. Pochodzące z nich węgielki drzewne i popioł nałożyły się na inne organiczne pozostałości związane z intensywnym użytkowaniem tego miejsca przez górnopaleolitycznych mieszkańców tworząc ówczesne „deptanisko”. Wskazuje na to również zadokumentowane natężenie przepalenia (aż do różowego zabarwienia) i nasycenie substancjami organicznymi, lessowego podłoża wykopu IV.

\section{Znaleziska}

Dotychczasowe badania ujawniły zróżnicowanie znalezisk w poszczególnych rejonach przebadanego obszaru (ryc. 8). W jego środkowej części (wykopy I, II i VI) wystapiła koncentracja ponad 800 kostnych fragmentów niemal wyłącznie mamuta (Mammuthus primigenius; wyróżniono pięć osobników) i jedną kość renifera (Rangifer tarandus), zalegających w układzie nieanatomicznym (ryc. 9, 10). Na podstawie wstępnej analizy paleozoologicznej materiałów kostnych uzyskanych podczas pierwszego sezonu badawczego ustalono, że wśród 151 szczątków mamuta znajdowało się między innymi 38 fragmentów żeber, 19 fragmentów kręgosłupa, 11 fragmentów kości długich i 40 innych fragmentów szkieletu. Ponadto znaleziono 18 fragmentów zębów i fragment żuchwy z zębami pochodzących od 12-14-letniego osobnika. Inny fragment szkieletu należał do 26-letniego mamuta (Wojtal, Cyrek, Sytnyk 2001, s. 137-142). Obecność charakterystycznych spiralnych złamań na fragmentach kości długich jest świadectwem wydobywania z nich szpiku. Na wielu szczątkach kostnych występują rozmaite rysy i zagładzenia, z których część ma prawdopodobnie intencjonalny charakter związany z czynnością oddzielania mięsa od kości przez paleolitycznych łowców; spostrzeżenia te zostaną zweryfikowane w trakcie badań tafonomicznych. Powyższe ustalenia sugerują, że opisana koncentracja powstała w miejscu ćwiartowania tusz zwierzęcych (zabitych lub padłych w okolicy mamutów) na terenie obozowiska łowieckiego (,butchering site”), gdzie należy spodziewać się stanowisk typu „killing site's”. Mikrostratygrafia w obrębie wspomnianej koncentracji 


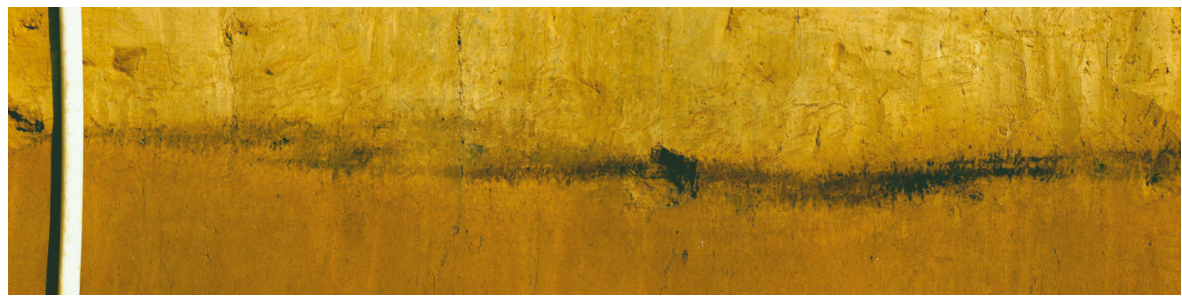

Ryc. 6. Halicz, Ukraina, stanowisko I. Fragment południowo-zachodniego profilu wykopu VI z trójdzielną I warstwą kulturową (fot. K. Cyrek)

Fig. 6. Halych, Ukraine, site I. Part of south-western cross-section of the excavation trench VI with triple cultural layer I (phot. by K. Cyrek)

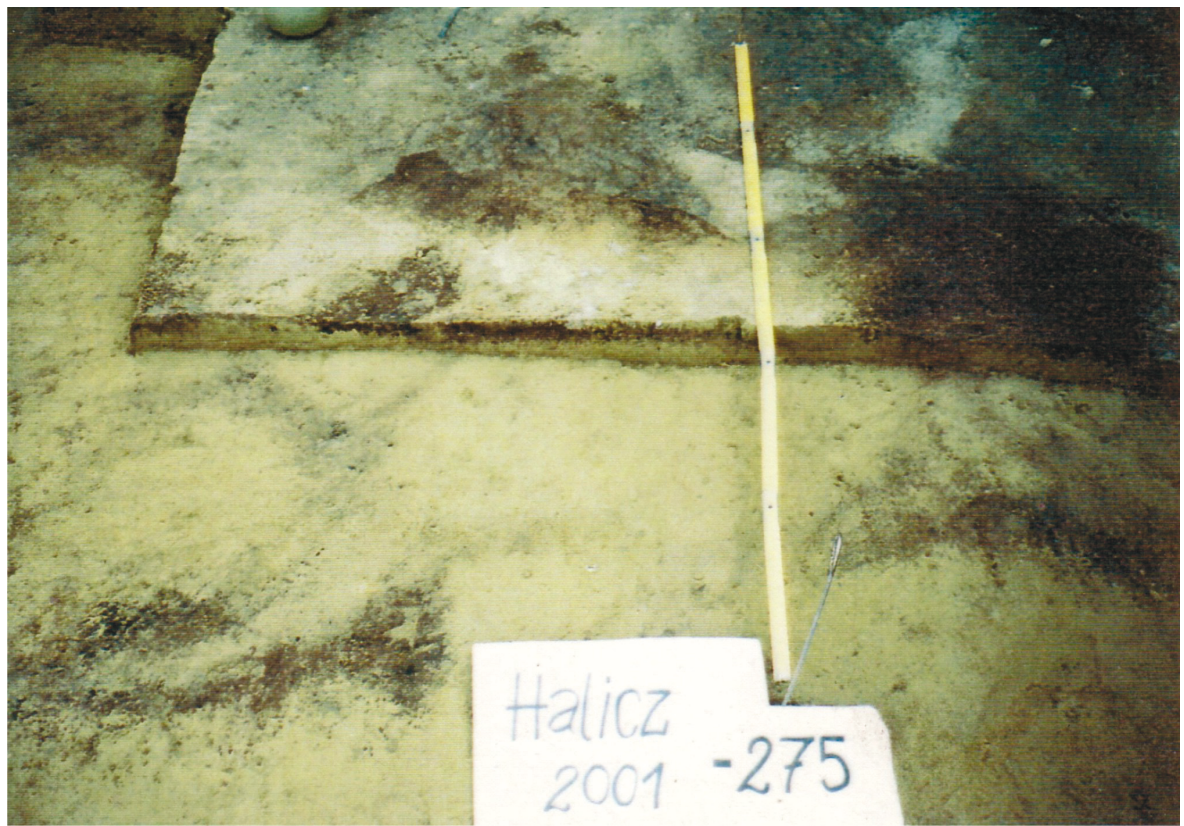

Ryc. 7. Halicz, Ukraina, stanowisko I. Wykop IV - pozostałości palenisk z dwóch faz zasiedlenia (fot. K. Cyrek)

Fig. 7. Halych, Ukraine, site I. Excavation trench IV - remains of the hearths from two phases of inhabitation (phot. by K. Cyrek)

była mało czytelna z uwagi na duże rozmiary kości oraz możliwość ich podepozycyjnych przesunięć w głąb sedymentu, co spowodowało, że w chwili odkrycia tworzyły one jeden zwarty poziom, uniemożliwiając wydzielenie ewentualnych subpoziomów (ryc. 11). Udało się jednak zaobserwować kilka niewielkich skupisk węgielków drzewnych zalegających poniżej poszczególnych kości, co sugeruje przynajmniej dwie fazy zasiedlenia tego rejonu stanowiska. Bezpośrednio na wschód od opisanych wyżej szczątków kostnych, 
wokół palenisk oraz w ich obrębie, wystąpiła nierównomierna koncentracja wyrobów krzemiennych (wykopy IV i IVa), stanowiąca prawdopodobnie efekt nałożenia na siebie kilku krzemienic (ryc. 8).

W wyniku trójwymiarowej lokalizacji każdego z ponad siedmiu tysięcy wyrobów krzemiennych udało się (w przeciwieństwie do kości) wyodrębnić trzy poziomy ich występowania w postaci mechanicznych warstw niwelacyjnych o łącznej miąższości $30 \mathrm{~cm}$ (od 295 do $265 \mathrm{~cm}$ od reperu). Ta mikrostratygraficzna analiza przekonuje, że co najmniej trzykrotnie przebywano na terenie objętym badaniami, za każdym razem pozostawiając po sobie wyroby krzemienne (ryc. 12). Każdy z tych pobytów można powiązać stratygraficznie ze wspomnianymi wyżej organicznymi warstewkami-pasemkami, paleniskami oraz kośćmi. Korelacja wyników analizy planigraficznej i mikrostratygraficznej przeprowadzonej dla poszczególnych kategorii znalezisk sugeruje obecność co najmniej trzech faz zasiedlenia terenu stanowiska w górnym paleolicie.

Pozostałości najstarszego (Ic) poziomu zasiedlenia zachowały się na głębokości niwelacyjnej od 290 do $295 \mathrm{~cm}$ w postaci słabo widocznych ,szarości”, rozproszonych i nielicznych wyrobów krzemiennych i trudnej do określenia (ale niewielkiej) liczby kości. W porównaniu z młodszymi poziomami, został on najbardziej podepozycyjnie zniszczony. Najlepiej zachowany i najbogatszy w znaleziska środkowy poziom zasiedlenia (Ib) odnotowano na głębokości od 275 do $285 \mathrm{~cm}$. Tworzyło go palenisko nr 2, zgrupowane wokół niego (z dwoma skupiskami na północ i północny zachód) wyroby krzemienne i położona na wschód koncentracja kości zwierzęcych (ryc. 13). Najmłodszy poziom zasiedlenia (Ia) wystąpił na głębokości od 265 do $270 \mathrm{~cm}$ i zachował się w postaci paleniska nr 1 i sąsiadującej bezpośrednio od północy koncentracji wyrobów krzemiennych oraz rozproszonych pojedynczych kości (ryc. 14). Na wszystkich trzech poziomach zasiedlenia odnotowano niewielkie plamy oraz skupiska bryłek koloru malinowego, które okazały się hematytowymi konkrecjami; ich skład chemiczny nie został jeszcze zbadany.

Zdecydowana większość znalezisk odnotowana w danym poziomie może być z nim łączona, chociaż niewątpliwie w lessowym podłożu nieliczne wyroby podepozycyjnie mogły zmienić swoje pierwotne położenie. Trudno też dokładnie określić jaką część przebadanego obszaru zajmowały poszczególne poziomy zasiedlenia, bo nie wszędzie każdy z nich pozostawił ślady. Należy przy tym pamiętać, że przebadany obszar to tylko nieokreślony bliżej fragment całej zasiedlonej w górnym paleolicie przestrzeni. 
[16]

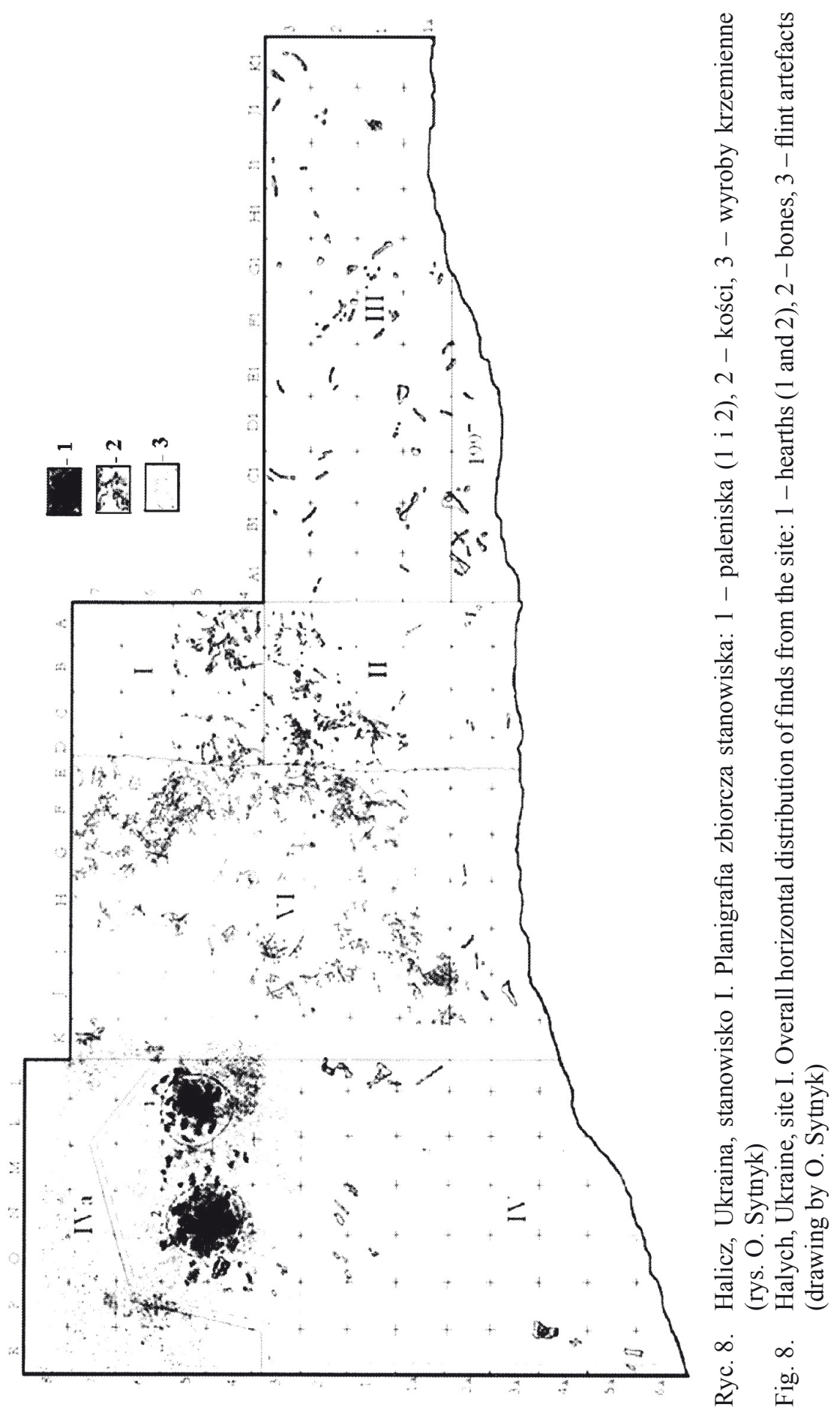




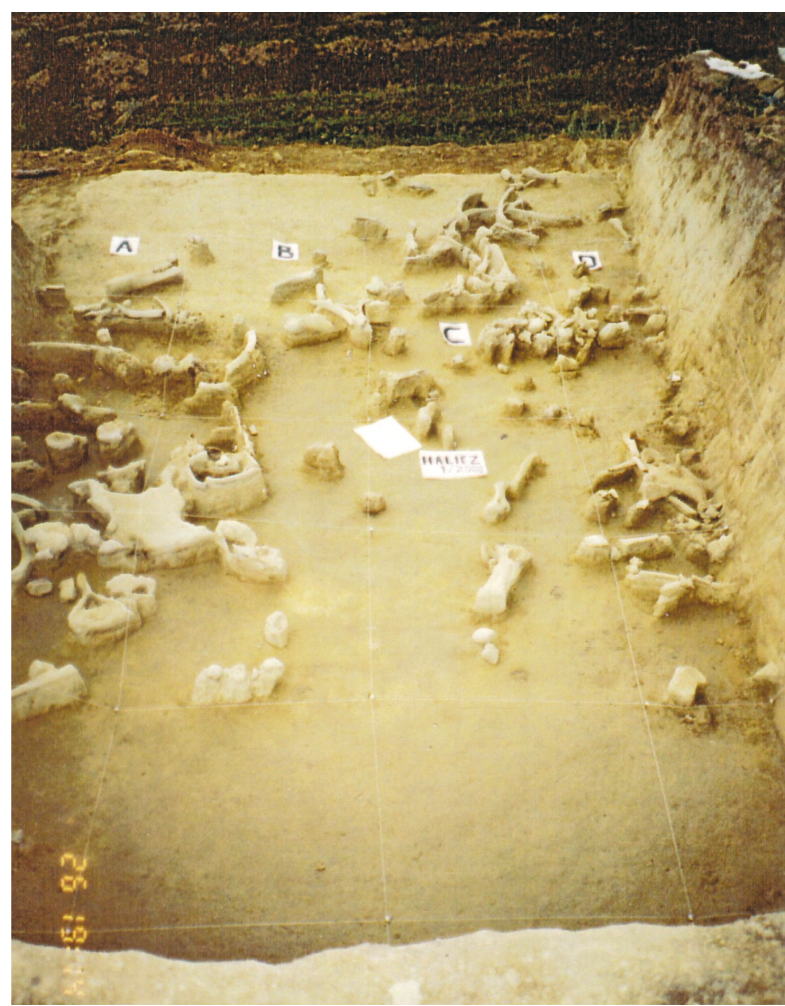

Ryc. 9. Halicz, Ukraina, stanowisko I. Wykop I/II - koncentracja kości mamuta (fot. K. Cyrek)

Fig. 9. Halych, Ukraine, site I. Excavation trench I/II - cluster of mammoth bones (phot. by K. Cyrek)

\section{Analiza wyrobów krzemiennych}

Inwentarz wyrobów krzemiennych pochodzących z całego przebadanego obszaru, które zaliczono do I warstwy kulturowej, liczy 7696 okazów. Wśród nich wydzielono kilka kategorii (tab. 1). Analizie technologicznej poddano jednak tylko 5215 wyrobów z wykopów IV i IVa (67,80 \% całości), co związane było - jak już wspomniano - z występowaniem w tej części stanowiska zwartych skupisk, w trzech poziomach niwelacyjnych. W sumie, w koncentracjach wokół palenisk znaleziono 4708 wyrobów, z czego do poziomu Ic zaliczono 2199, do Ib - 2144, do Ic zaś - 365 .

Wśród wyrobów zaliczonych do poziomu Ic (365 szt.) znajdują się 4 rdzenie $(1,1 \%), 33$ narzędzia retuszowane $(9,0 \%), 52$ wióry $(14,2 \%), 49$ wiórków o szerokości poniżej 12 mm (13,3\%), 47 odłupków (12,9\%), 26 nieokreślonych fragmentów półsurowca (7,1\%), 20 fragmentów surowca krzemiennego 


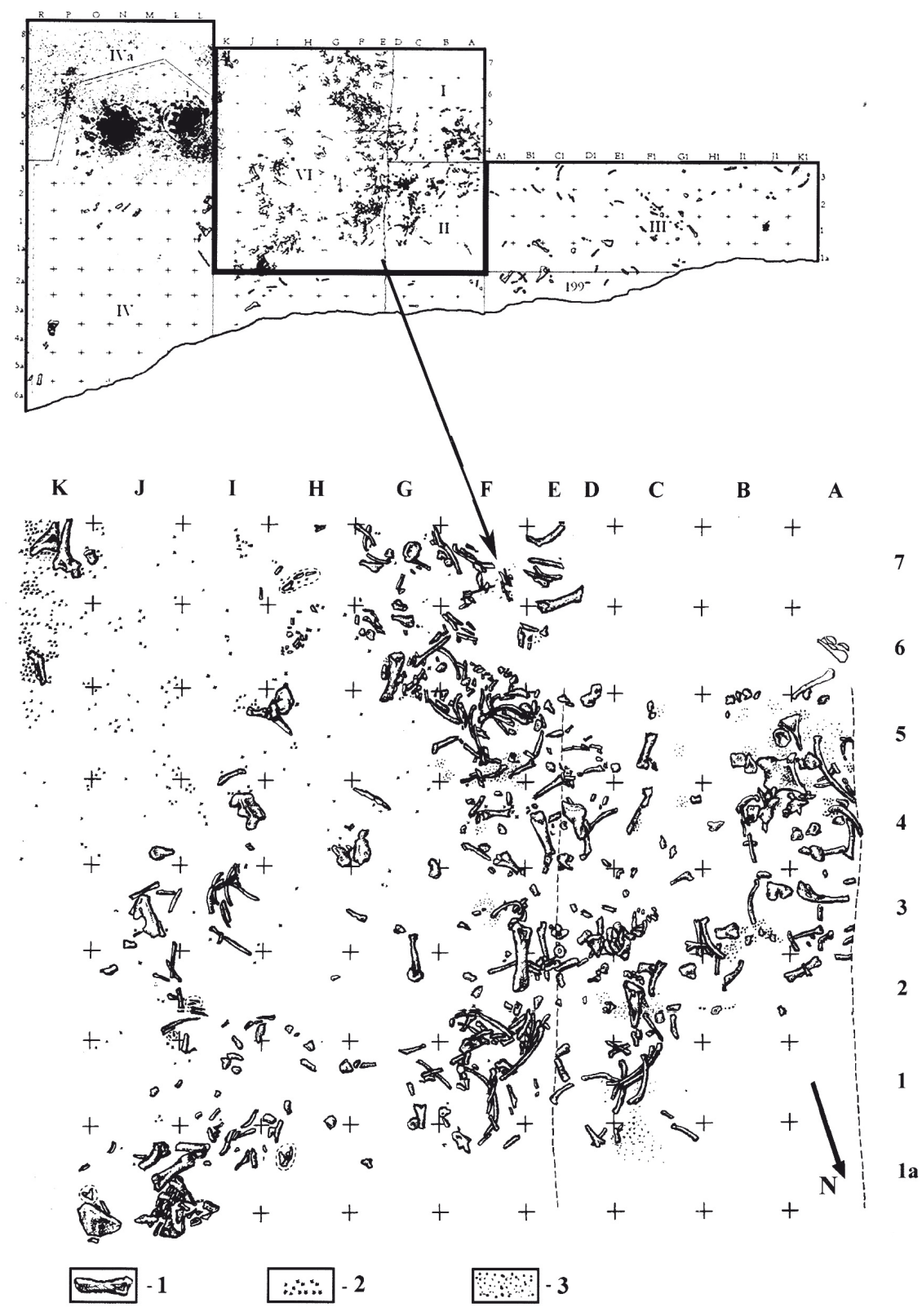

Ryc. 10. Halicz, Ukraina, stanowisko I. Wykop I/II - koncentracja kości mamuta; planigrafia: 1 - kości, 2 - wyroby krzemienne, 3 - węgle drzewne (rys. O. Sytnyk)

Fig. 10. Halych, Ukraine, site I. Excavation trench I/II - cluster of mammoth bones; horizontal distribution of finds: 1 - bones, 2 - flint artefacts, 3 - charcoal (drawing by O. Sytnyk) 


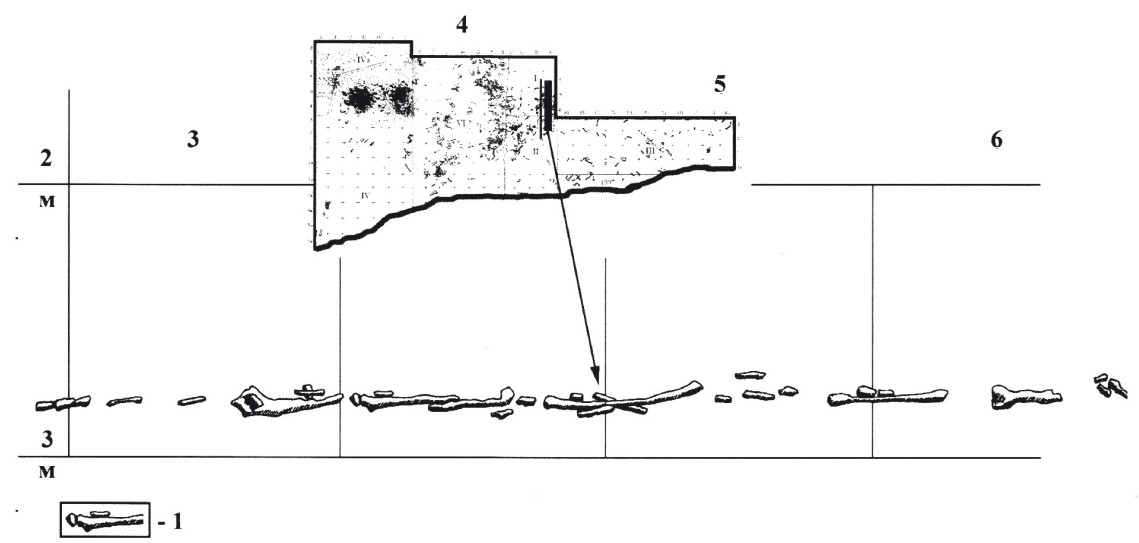

Ryc.11. Halicz, Ukraina, stanowisko I. Wykop I/II - koncentracja kości mamuta w profilu (rys. O. Sytnyk)

Fig.11. Halych, Ukraine, site I. Excavation trench I/II - cluster of mammoth bones in cross-section (drawing by O. Sytnyk)

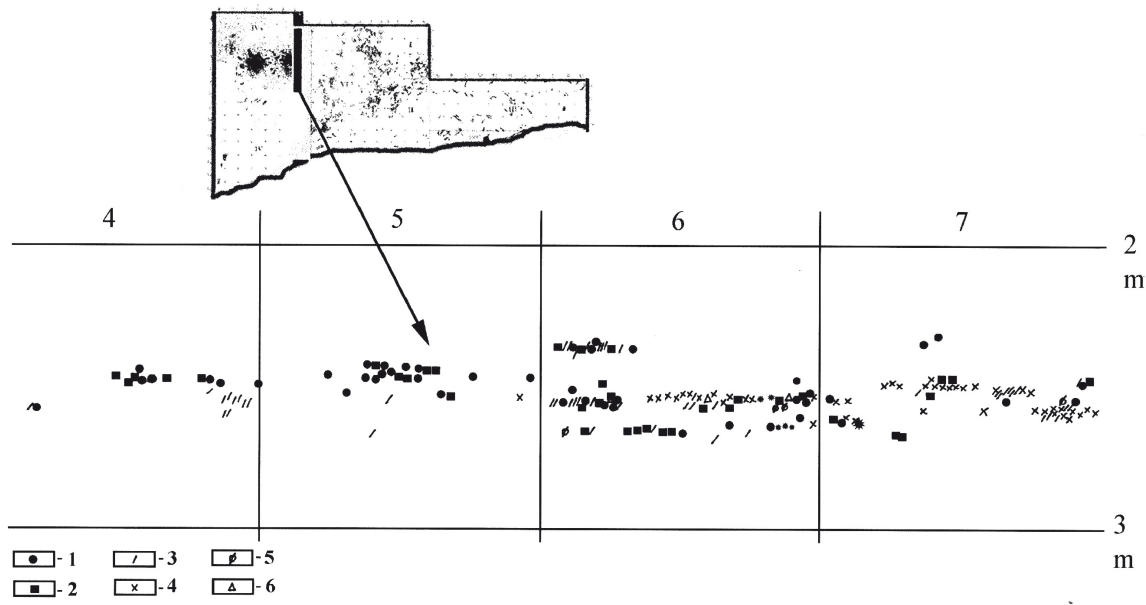

Ryc. 12. Halicz, Ukraina, stanowisko I. Mikrostratygrafia w obrębie koncentracji wyrobów krzemiennych: 1 - odłupki, 2 - wióry, 3 - wiórki, 4 - fragmenty odłupków, 5 - rdzenie i fragmenty surowca, 6 - narzędzia (rys. O. Sytnyk)

Fig. 12. Halych, Ukraine, site I. Micro-stratigraphy within the cluster of flint artefacts: 1 - flakes, 2 - blades, 3 - bladelets, 4 - flake fragments, 5 - cores and fragments of raw material, 6 - tools (drawing by O. Sytnyk) 


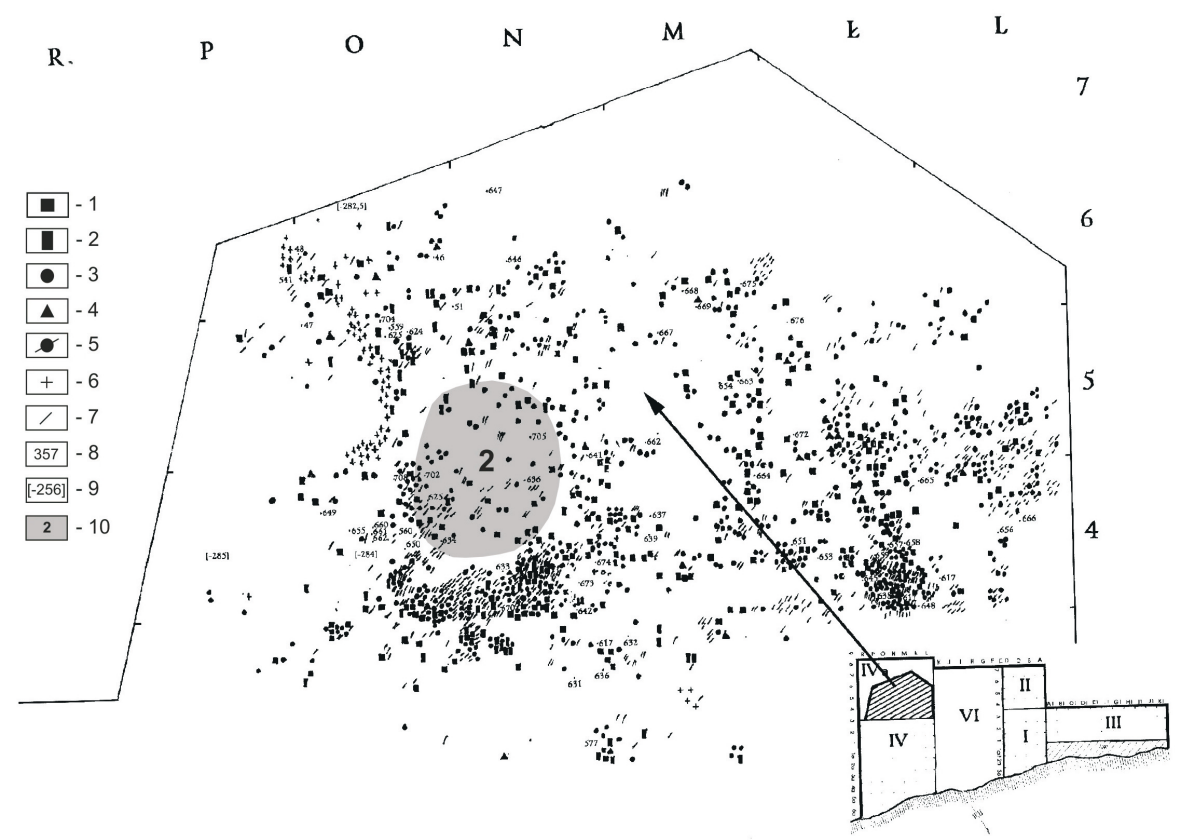

Ryc. 13. Halicz, Ukraina, stanowisko I. Wykop IV - planigrafia poziomu kulturowego Ib: 1 - odłupki, 2 - wióry, 3 - wióroodłupki, 4 - narzędzia, 5 - rdzenie, 6 - fragmenty surowca, 7 - łuski, 8 - numer inwentarza polowego, 9 - głębokość zalegania wyrobów krzemiennych, 10 - zasięg paleniska nr 2 (rys. O. Sytnyk)

Fig. 13. Halych, Ukraine, site I. Excavation trench IV - horizontal distribution of finds from the cultural level Ib : 1 - flakes, 2 - blades, 3 - blade-like-flakes, 4 - tools, 5 - cores, 6 - raw material fragments, 7 - chips, 8 - number of field inventory, 9 - depth of the occurrence of flint artefacts, 10 - the range of hearth number 2 (drawing by O. Sytnyk)

(5,5\%) i 1 otoczak piaskowca. Zwraca uwage przewaga wiórów i mikrowiórków nad odłupkami, ponadto stosunkowo duży udział form retuszowanych, do których zaliczono również te z retuszem użytkowym oraz brak (prawdopodobnie przypadkowy) łusek. Tylko 13 wiórów jest zachowanych w całości, udział pozostałych fragmentów wierzchołkowych, środkowych i piętkowych jest podobny. Z kolei wśród wiórków odnotowano 14 całych okazów. Do wyrobów z wtórną obróbką (z retuszem; 33 szt.) zaliczono 11 wiórów retuszowanych, 5 wiórów mikroretuszowanych, 6 wiórków retuszowanych, 4 odłupki retuszowane. Inne narzędzia wystąpiły w pojedynczych egzemplarzach; są to: zgrzebło, drapacz, rylec, tylczak i mikrorylcowiec. Zwraca uwage brak większej liczby form wyraźnych typologicznie, które byłyby charakterystyczne kulturowo. 


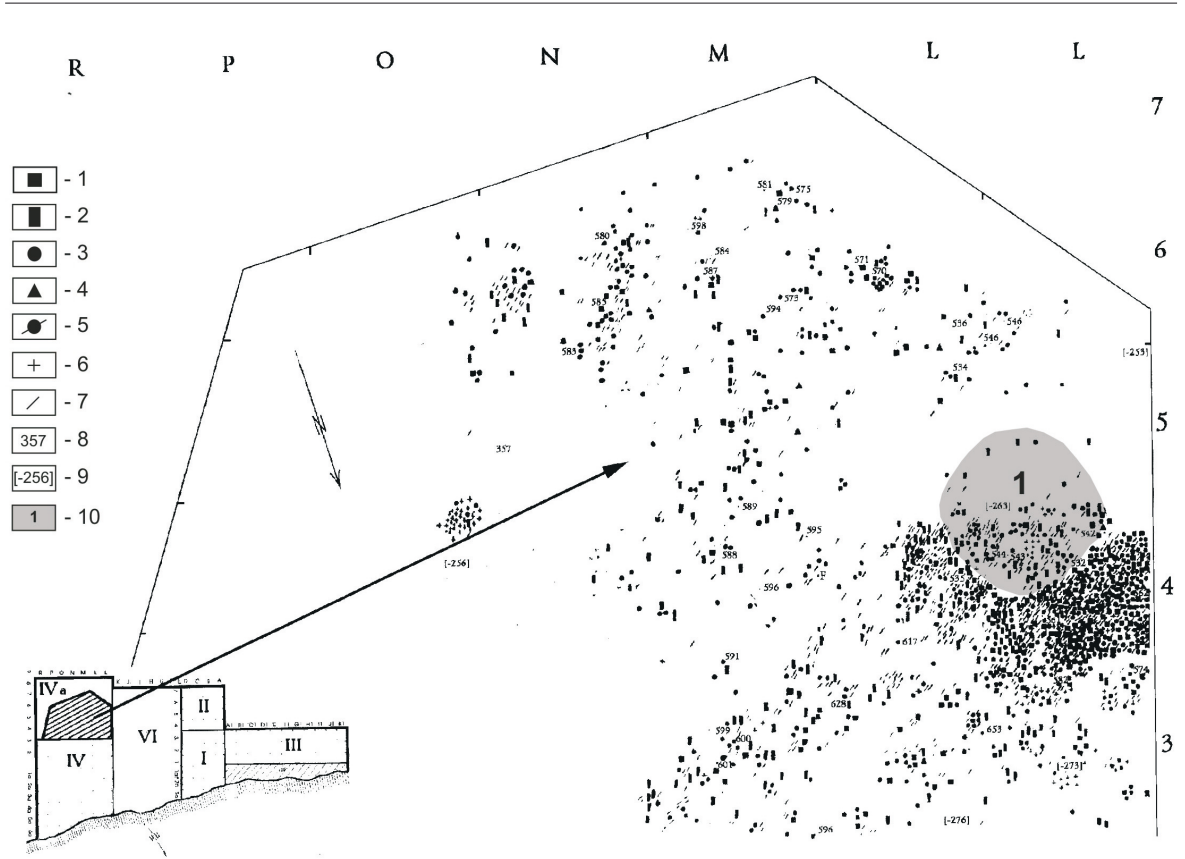

Ryc. 14. Halicz, Ukraina, stanowisko I. Planigrafia poziomu kulturowego Ia: 1 - odłupki, 2 - wióry, 3 - wióroodłupki, 4 - narzędzia, 5 - rdzenie, 6 - fragmenty surowca, 7 - łuski, 8 - numer inwentarza polowego, 9 - głębokość zalegania wyrobów krzemiennych, 10 - zasięg paleniska nr 1 (rys. O. Sytnyk)

Fig. 14. Halych, Ukraine, site I. Horizontal distribution of finds from the cultural level Ib : 1 - flakes, 2 - blades, 3 - blade-like-flakes, 4 - tools, 5 - cores, 6 -raw material fragments, 7 - chips, 8 - number of field inventory, 9 - depth of the occurrence of flint artefacts, 10 - the range of hearth number 1 (drawing by O. Sytnyk)

Tabela 1. Halicz I, Ukraina. Struktura inwentarza wyrobów krzemiennych

\begin{tabular}{|l|c|c|}
\hline \multicolumn{1}{|c|}{ Kategoria wyrobów } & Liczba (szt.) & Udzial (\%) \\
\hline Rdzenie & 39 & 0,5 \\
\hline Odłupki & 916 & 11,9 \\
\hline Wióry & 1412 & 18,5 \\
\hline Wiórki & 1167 & 15,2 \\
\hline Narzędzia retuszowane & 197 & 2,3 \\
\hline Łuski i mikroodpadki & 3714 & 48,3 \\
\hline Naturalne konkrecje & 171 & 2,2 \\
\hline Razem & $\mathbf{7 6 9 6}$ & $\mathbf{1 0 0}$ \\
\hline
\end{tabular}

Inwentarz związany z poziomem Ib (2132 szt.) stanowi 6 rdzeni $(0,3 \%)$, 104 narzędzia retuszowane (5,9\%), 147 wiórów (7,9\%), 362 wiórki (16,9\%), 
240 odłupki (11,2\%), 104 nieokreślone fragmenty półsurowca (4,9\%), 54 fragmenty krzemiennego surowca $(2,5 \%), 1115$ lusek i mikroodpadków o wymiarach poniżej $20 \mathrm{~mm}$ (52\%). Zwraca uwagę niewielki udział rdzeni i narzędzi, przewaga wiórów nad odłupkami oraz wiórków nad wiórami, a także wyjątkowo duża liczba łusek i mikroodpadków. Tylko 43 wióry są zachowane w całości, udział wierzchołkowych, środkowych i piętkowych fragmentów jest zbliżony. Natomiast wśród wiórków całych okazów jest 156, czyli niemal połowa tych wyrobów. Nasuwa się spostrzeżenie o częstszym łamaniu wiórów niż wiórków, prawdopodobnie intencjonalnie w ramach formowania narzędzi, natomiast $\mathrm{w}$ niewielu przypadkach łamano odłupki (37 szt.), dużo rzadziej wykorzystywane do formowania narzędzi. Wśród tych ostatnich przeważają rylce (11 szt.) i rylczaki (13 szt.) nad drapaczami (3 szt.); pojedynczo wystąpiły również skrobacz, wiertnik, wiór tylcowy i ostrze graweckie. Należy zaznaczyć, że również w klasycznych dla wschodniego grawetienu zespołach z Mołodowej, klasycznych form graweckich jest bardzo mało (Czernysz 1987).

Najbogatszy w wyroby krzemienne był poziom (Ia - 2199 szt.); wyróżniono w nim 8 rdzeni $(0,4 \%), 108$ narzędzi retuszowanych (4,8\%), 146 wiórów (6,6\%), 397 wiórków (18\%), 231 odłupków (10,5\%), 104 nieokreślone fragmenty półsurowca $(5,2 \%), 37$ fragmentów konkrecji krzemiennego surowca $(1,7 \%), 1125$ łusek i mikroodpadków $(51,1 \%), 12$ otoczaków piaskowca i kwarcytu $(0,5 \%)$. Podobnie jak w poprzednich poziomach, charakterystyczna jest przewaga zarówno wiórów, jak i wiórków nad odłupkami, a przede wszystkim łusek i mikroodpadków, które stanowią ponad połowę wszystkich wyrobów, przy czym należy pamiętać, że w rzeczywistości mogło ich być jeszcze więcej. Jak przekonują wyniki kontrolnego przepłukania próby lessowego sedymentu pobranego ze środkowej części jednej z dwóch krzemienic, w miejscu intensywnej obróbki krzemienia znaleziono liczne odpadki o rozmiarach od 1 do $3 \mathrm{~mm}$, nieuchwytne podczas eksploracji bez zastosowania flotacji. Równie zaskakujący jest bardzo niski udział rdzeni, najczęściej w szczątkowym stadium eksploatacji, co w połączeniu z niewielką liczbą surowych konkrecji (37 szt. może świadczyć o ograniczonym zapasie surowca przeznaczonego do obróbki, jakim dysponowano w tej fazie zasiedlenia. Podobnie jak w poziomie Ib zwraca uwagę przewaga fragmentów wiórów (113 szt.) nad całymi egzemplarzami (34 szt.) oraz wiórków, wśród których tylko 124 znaleziono w całości. Odłupki mają charakter nieudanych wiórów bądź form z zaprawy lub naprawy wiórowych rdzeni. Podsumowując, należy stwierdzić, że dla tej fazy zasiedlenia charakterystyczna była wiórowa i mi- 
krolityczna technika obróbki krzemienia. Odnosi się to również do inwentarzy z poziomów Ib i Ic (mimo mniejszej liczebności tego ostatniego), co pozwala określić je jako należące do tego samego technokompleksu.

W obróbce krzemienia bazowano na miejscowym naddniestrzańskim surowcu kredowym, który występuje w postaci otoczaków w pobliskiej dolinie Dniestru. Przyniesione stamtąd formy zaczątkowe i obłupnie, przerabiano na terenie stanowiska przy zastosowaniu techniki rdzenia jednopiętowego, w mniejszym stopniu dwupiętowego. Głównym celem były wióry i wiórki, z których wyrabiano większość retuszowanych narzędzi. Wśród tych ostatnich przeważają rylce, co ma prawdopodobnie związek z obróbką kości upolowanych mamutów. Spory udział form tylcowych jest świadectwem wyrobu zbrojonych kościanych lub drewnianych ostrzy czy harpunów związanych z łowieckimi zajęciami mieszkańców.

Struktury zespołów wyrobów krzemiennych z poziomów Ia, Ib i Ic charakteryzują się przewagą wiórów i wiórków nad odłupkami, bardzo wysokim udziałem łusek i mikroodpadków i sporym udziałem narzędzi retuszowanych przy nielicznej obecności rdzeni. Zdaje się to świadczyć o podomowym charakterze tych zespołów, jednak ze znaczącym udziałem funkcji pracownianej w typie pracowni przydomowej.

Obok podobnej struktury, również morfologia wszystkich wyrobów pochodzących z I warstwy kulturowej jest identyczna, zatem szczegółowa analiza techniki obróbki krzemienia zostanie przeprowadzona zbiorczo dla całego inwentarza z wykopów IV i IVa. W sumie, łącznie z okazami znalezionymi poza wspomnianymi koncentracjami wokół palenisk, jest to zbiór liczący 5215 sztuk. Po pominięciu takich form jak łuski, odpadki i nieokreślone okazy, szczegółowej analizie poddano 1980 wyrobów (28 rdzeni i form rdzeniowych, 420 wiórów, 818 wiórków, 587 odłupków i 127 narzędzi retuszowanych). Stwierdzono obecność zaledwie dwóch obłupni, z płaską, odboczną zaprawą jednej pięty i praodłupni. Ponadto wystąpiły cztery zaczątkowce rdzeni jednopiętowych $\mathrm{z}$ negatywami po odbiciach formujących płaską piętę oraz konkrecje piaskowca karpackiego ze śladami zaczątkowej obróbki.

Na podstawie morfologii, sposobu zaprawy oraz metody uzyskiwania półsurowca, wydzielono 10 typów rdzeni (ryc. 15):

- Typ 1 (4 szt.) - rdzeń jednopiętowy z pojedynczą, płaską odłupnią o równoległych negatywach wiórowych i odłupkowych; pięta zaprawiona i naprawiana równoległymi odbiciami od strony odłupni; tył surowy (ryc. 16: 1, 2; ryc. 17: 3). 
- Typ 2 (3 szt.) - rdzeń jednopiętowy z pojedynczą, wypukłą odłupnią o równoległych negatywach wiórowych; pięta o kącie rdzeniowym prostym lub ostrym, zaprawiona i naprawiana od strony odłupni; tył surowy (ryc. 18: 1, 2; ryc. 19: 2).

- Typ 3 (2 szt.) - rdzeń jednopiętowy (podstożkowy) z pojedynczą wypukłą, podtrójkatną odłupnią o zbieżnych negatywach wiórowych; pięta silnie ukośna ze śladami zaprawy i naprawy; tył surowy (ryc. 17: 1).

- Typ 4 (1 szt.) - rdzeń jednopiętowy z dwoma odłupniami usytuowanymi względem siebie pod kątem zbliżonym do prostego; odłupnie płaskie $\mathrm{z}$ równoległymi negatywami wiórowymi i wióroodłupkowymi; pięta lekko nachylona ze śladami zaprawy i facetowania krawędzi; tył częściowo zaprawiony płaskimi odbiciami (ryc. 20: 1).

- Typ 5 (1 szt.) - rdzeń dwupiętowy, rozdzielnoodłupniowy lub ze zmianą orientacji o wypukłej, zakolonej na boki odłupni, z wiórowymi równoległymi negatywami; pięta naprawiana (ryc. 20: 3).

- Typ 6 (1 szt.) - rdzeń ze zmianą orientacji, trzema piętami i trzema płaskimi odłupniami o równoległych negatywach wiórowych (ryc. 20: 2).

- Typ 7 (4 szt.) - rdzeń jednopiętowy o wypukłej, zakolonej na boki odłupni z negatywami wiórowymi; odłupnia zaprawiona dwustronnym, krawędziowym zatępiskiem; boki zaprawione odbiciami od tyłu rdzenia; pięta ukośna ze śladami naprawy (ryc. 21: 1,2).

- Typ 8 (2 szt.) - rdzeń dwupiętowy o prostej lub wypukłej i wąskiej odłupni z równoległymi negatywami wiórków, usytuowanej na piętkowej płaszczyźnie odłupka z którego uformowano rdzeń (ryc. 19: 3, 4).

- Typ 9 (2 szt.) - rdzeń dwupiętowy wiórowy, wspólnoodłupniowy o odłupni zachodzącej na zaprawione boki; pięty ukośne ze śladami naprawy, zaprawione krawędziowym zatępiskiem obejmującym również tył rdzenia (ryc. 18: 3; ryc. 19: 1).

- Typ 10 (2 szt.) - rdzeń dwupiętowy wiórkowy wspolnoodłupniowy o poprzecznie załamanej odłupni i skośnych, odnawianych piętach; boki ukształtowane odbiciami od strony odłupni; tył uformowany przez krawędziowe zatępisko (ryc. 20: 4; ryc. 21: 3).

Podsumowując powyższą charakterystykę należy podkreślić wyraźną przewagę rdzeni jednopiętowych (14 szt.) nad dwupiętowymi (7 szt.) i ze zmienioną orientacją (1 szt.). Zapewne niektóre formy dwupiętowe w końcowej fazie eksploatacji przybierały postać jednopiętowych. Przewaga rdzeni z negatywami wiórowymi (61\%) nad wiórowo-odłupkowymi (39\%), przy braku odłupkowych, jednoznacznie określa główny cel rdzeniowania, któ- 


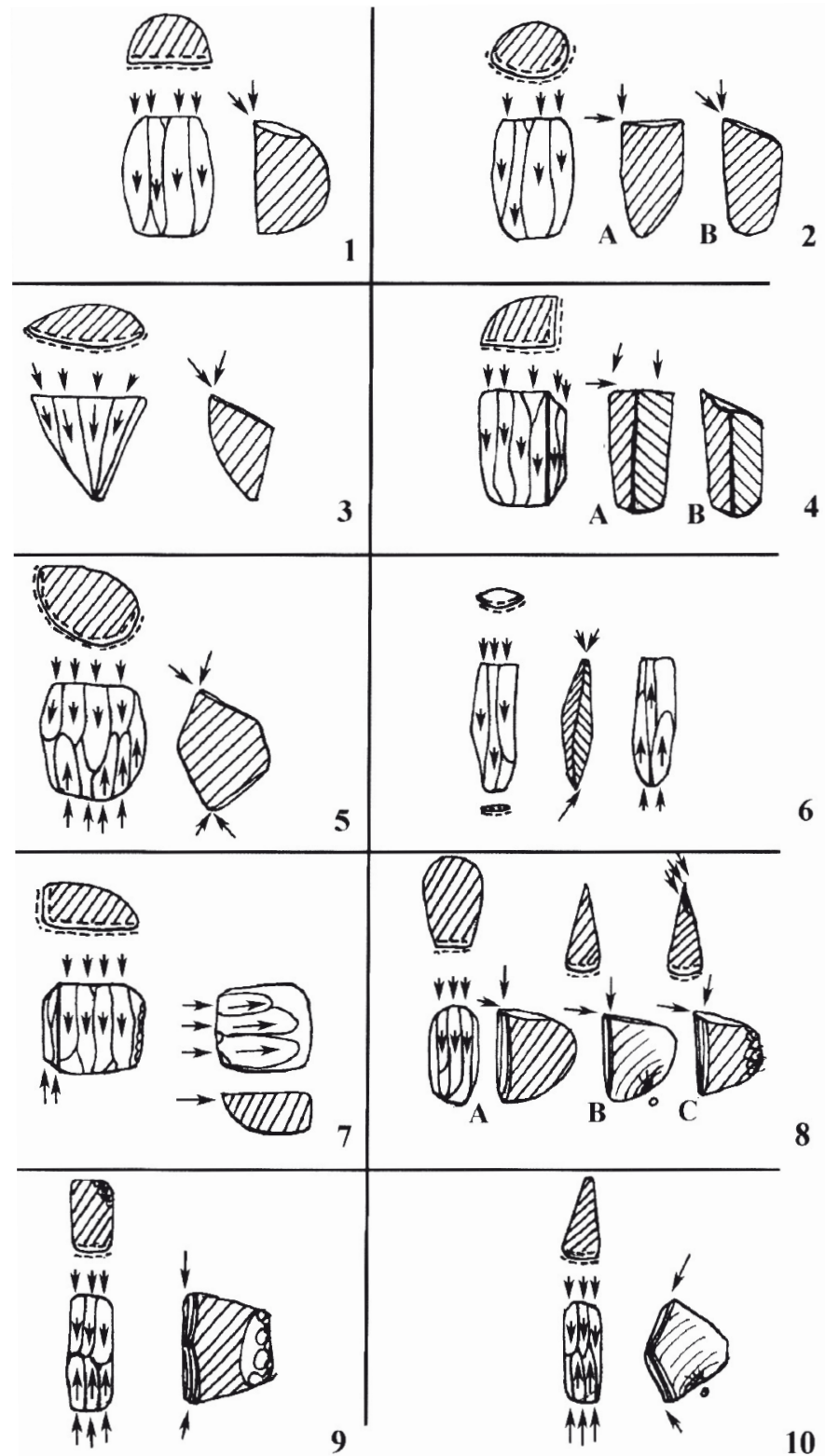

Ryc. 15. Halicz, Ukraina, stanowisko I. Schemat typologii rdzeni (rys. O. Sytnyk)

Fig. 15. Halych, Ukraine, site I. Schematic typological diagram of cores (drawing by O. Sytnyk)

rym było pozyskanie wiórów i wiórków. Najczęściej zaprawiano pięty rdzeni, rzadziej odłupnie, tyły i boki. Zaprawa miała charakter bardzo elastyczny, dostosowany do kształtu wodnych otoczaków surowca krzemiennego. 

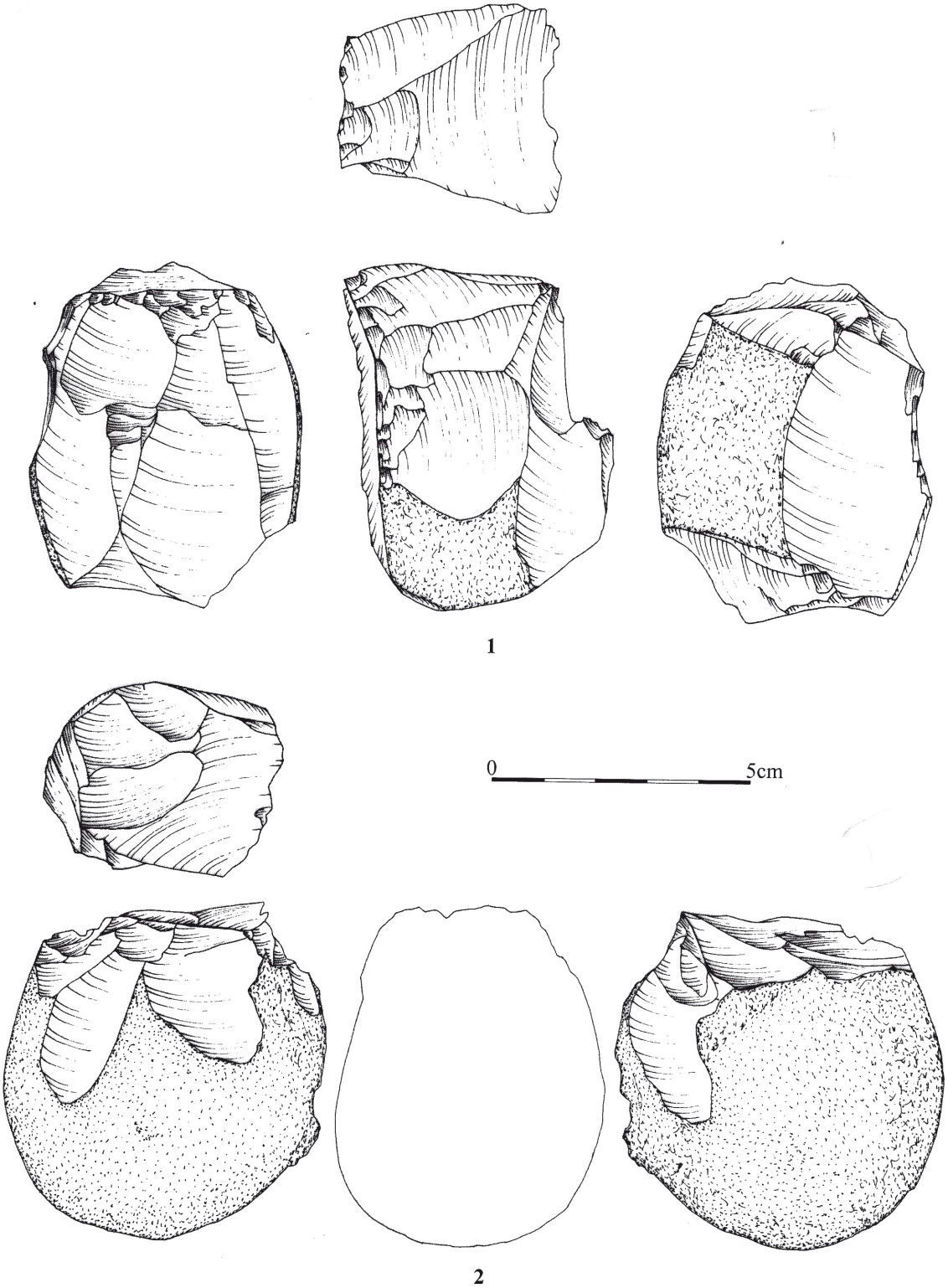

Ryc. 16. Halicz, Ukraina, stanowisko I. Wyroby krzemienne-rdzenie (rys. M. S udoł) Fig. 16. Halych, Ukraine, site I. Flint artefacts - cores (drawing by M. Sudoł)

Często stosowano zabieg prawcowania (wyrównywania) krawędzi pięty oraz jej odnawiania, rzadziej odnawiano odłupnie.

Wśród 420 wiórów, większość (265 szt.) stanowią fragmenty przypiętkowe (113 szt.), środkowe (76 szt.) i wierzchołkowe (103 szt.). Analiza morfo- 

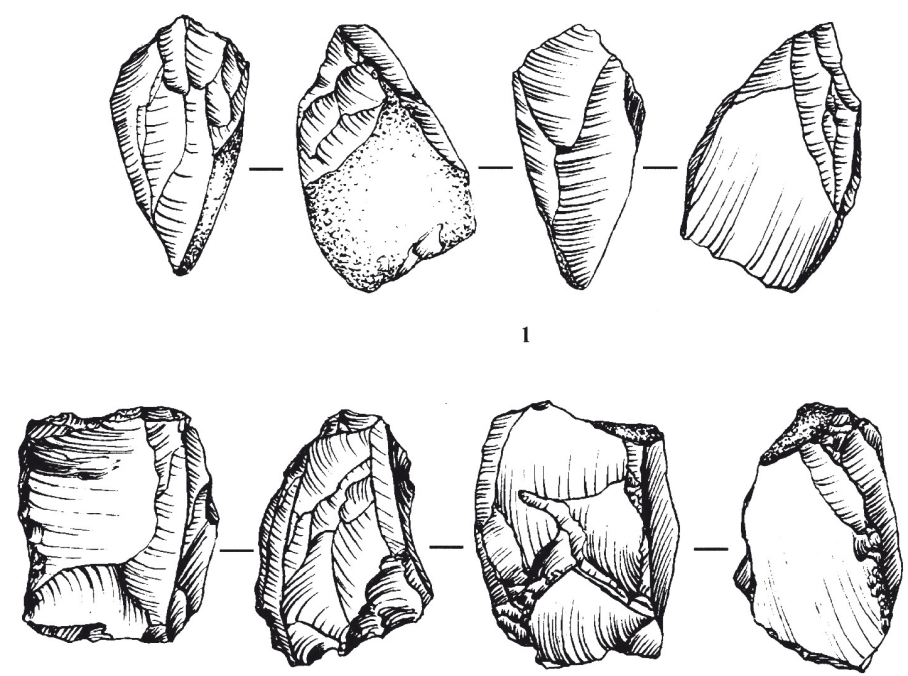

2

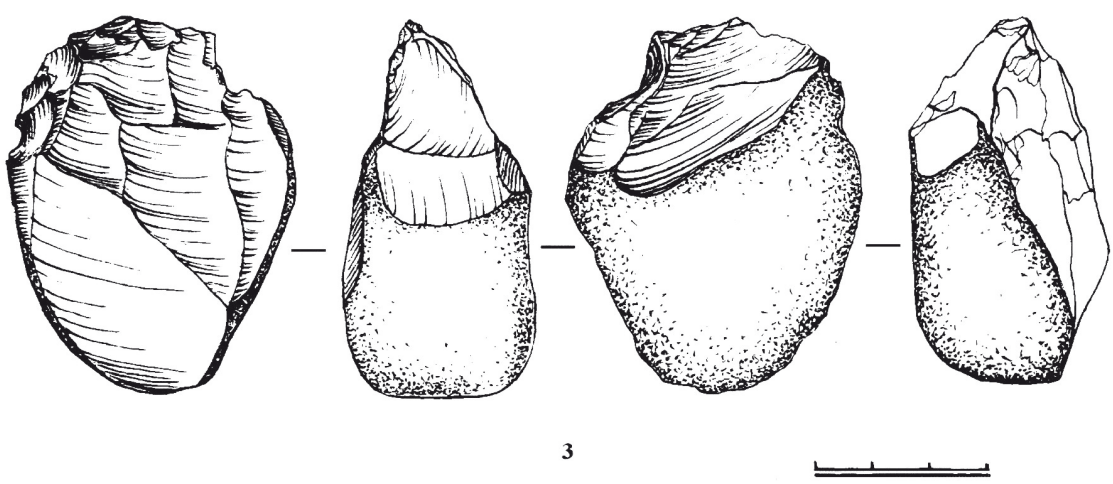

Ryc. 17. Halicz, Ukraina, stanowisko I. Wyroby krzemienne-rdzenie (rys. M. Sudoł) Fig. 17. Halych, Ukraine, site I. Flint artefacts - cores (drawing by M. Sudoł)

metryczna wykazała, że wraz ze wzrostem długości całych wiórów, maleje ich liczba. Dla inwentarza z Halicza charakterystyczna jest mała liczba dużych wiórów, z czym zgodny wydaje się być znaczący udział mikrowiórów (czyli wiórków) w całym inwentarzu. Odnośnie proporcji wiórów zwraca uwagę niewielka przewaga (61,3\%) form, w których długość jest dwa razy większa od szerokości, przy bardzo małym udziale okazów o proporcji 4:1. Jeśli chodzi o piętki to przeważają punktowe i krawędziowe (odpowiednio 44,8 i 39,5\%) nad negatywowymi i facetowanymi (odpowiednio 10,7 i 4,8\%), podobnie zresztą jak wśród mikrowiórków. Kąt piętkowy najczęściej jest 

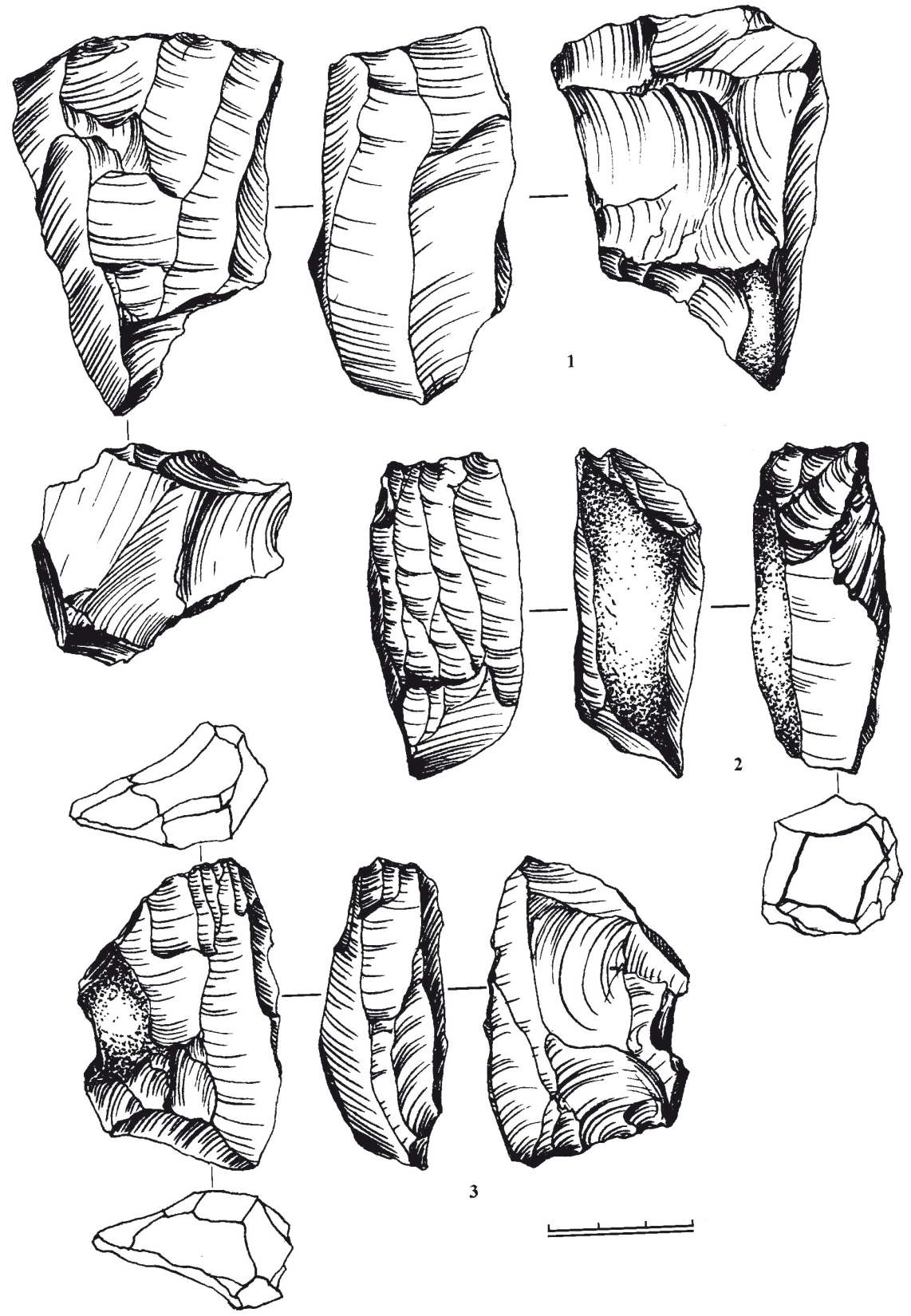

3

Ryc. 18. Halicz, Ukraina, stanowisko I. Wyroby krzemienne-rdzenie (rys. M. Sudoł) Fig. 18. Halych, Ukraine, site I. Flint artefacts - cores (drawing by M. Sudoł) 

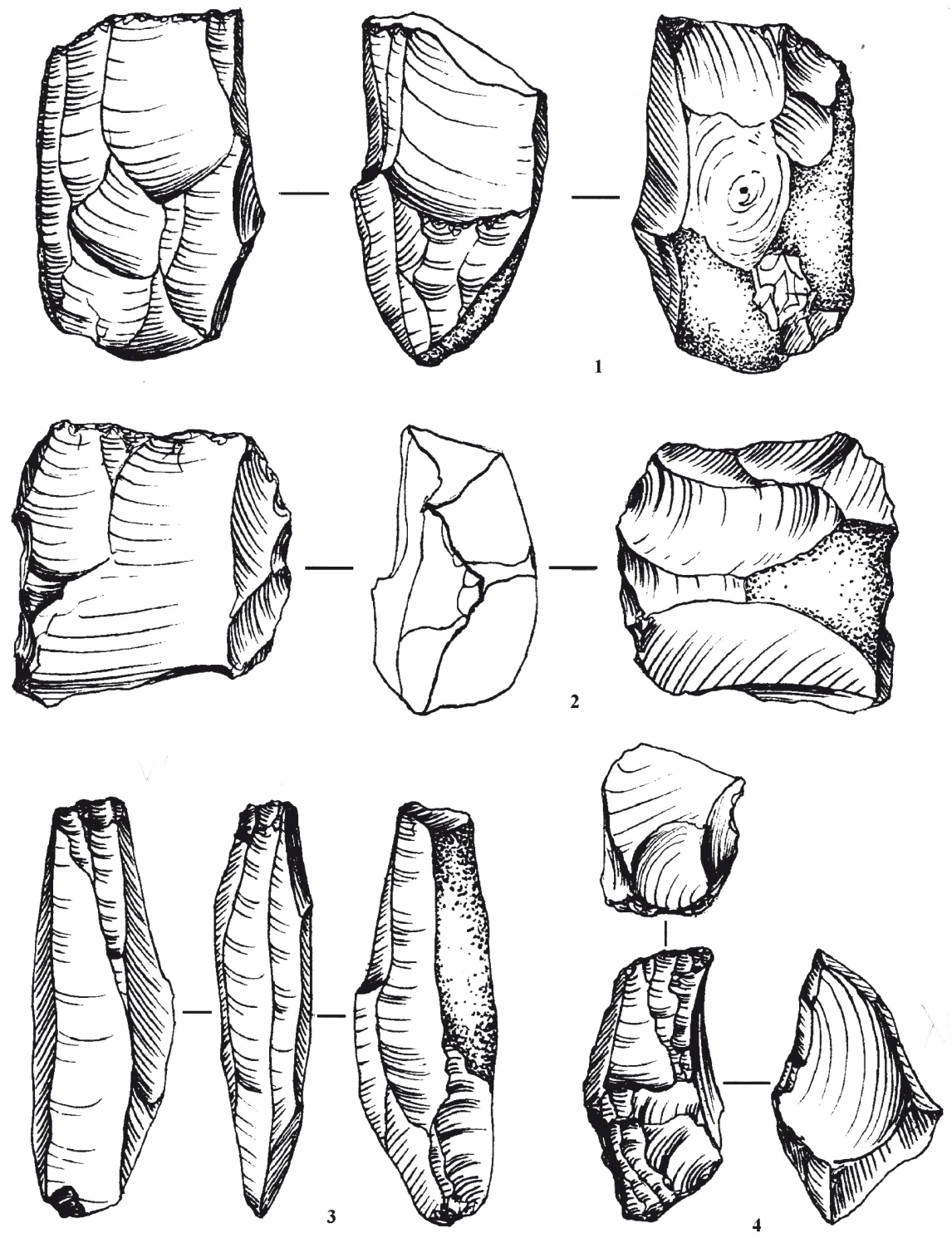

Ryc. 19. Halicz, Ukraina, stanowisko I. Wyroby krzemienne-rdzenie (rys. M. Sudoł) Fig. 19. Halych, Ukraine, site I. Flint artefacts - cores (drawing by M. Sudoł)

prosty $(43,9 \%)$ bądź rozwarty $(39,5 \%)$. Większość wiórów to okazy negatywowe $(51,7 \%)$ lub też mające poniżej 50\% kory (35,6\%) przy małym udziale form z korą (10,2\%). Negatywy na górnej stronie w większości przypadków $(35,6 \%)$ charakteryzują się równoległym i jednokierunkowym układem, 
[30]
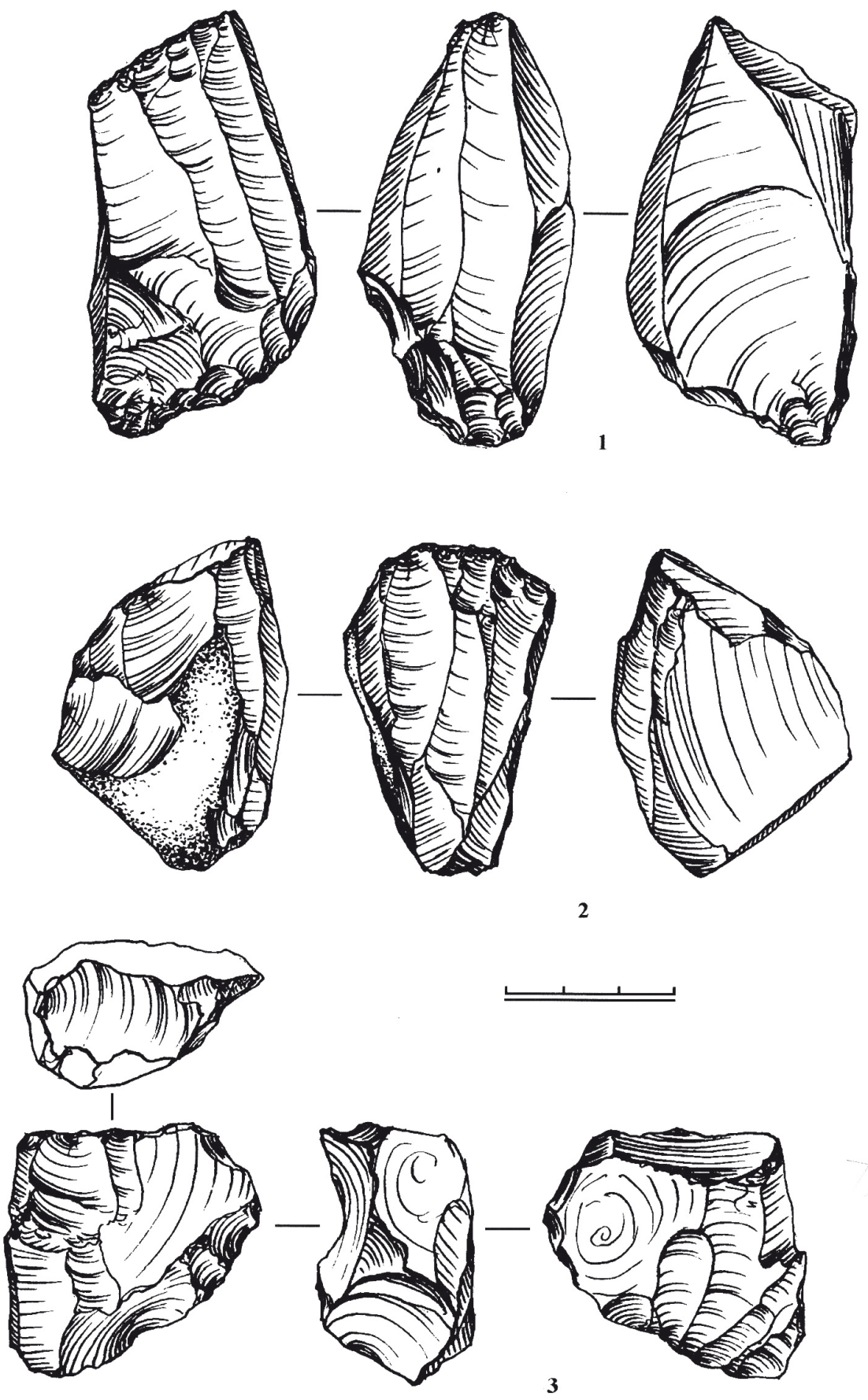

Ryc. 20. Halicz, Ukraina, stanowisko I. Wyroby krzemienne-rdzenie (rys. M. Sudoł) Fig. 20. Halych, Ukraine, site I. Flint artefacts - cores (drawing by M. Sudoł) 

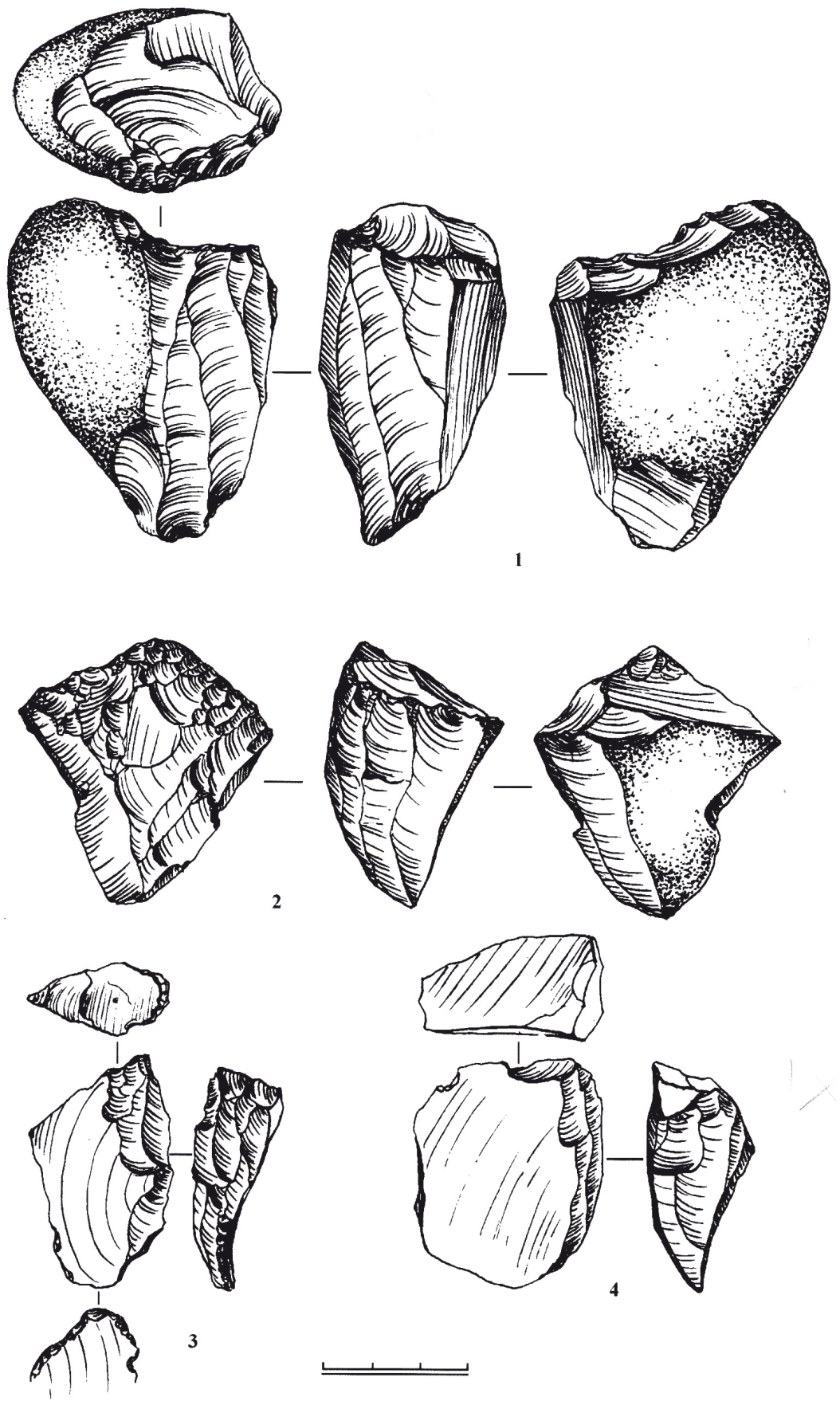

Ryc. 21. Halicz, Ukraina, stanowisko I. Wyroby krzemienne-rdzenie (rys. M. Sudoł) Fig. 21. Halych, Ukraine, site I. Flint artefacts - cores (drawing by M. Sudoł) 
znacznie rzadziej natomiast równoległym i skośnym $(14,6 \%)$ oraz prostopadłym i skośnym $(9,7 \%)$. Udział wiórów o poprzecznym przekroju trójkątnym i trapezowatym jest zbliżony, w przekrojach podłużnych zaś przeważają formy proste $(52,6 \%)$ nad podgiętymi $(28,2 \%)$ i wygiętymi $(13,6 \%)$. Sęczki najczęściej są bardzo wyraźne (43,9\%) bądź wyraźne (50,7\%).

Wśród 587 odłupków większość $(74,0 \%)$ stanowią okazy całe z przewagą małych liczących od 2 do $4 \mathrm{~cm}$ długości (82\%). Podobnie, jak to miało miejsce wśród wiórów, przeważają odłupki bez śladów kory na górnej stronie, chociaż w tym przypadku nieco większy jest udział okazów częściowo pokrytych korą. Układ negatywów na górnej stronie najczęściej jest równoległy jednokierunkowy (57,1\%) i skośny $(16,6 \%)$. Wśród piętek, podobnie jak w przypadku wiórów, wyraźnie przeważają punktowe i krawędziowe (odpowiednio 21,2 i $34,9 \%$ ), chociaż udział negatywowych i facetowanych jest wyraźnie wyższy (odpowiednio 31,1 i $11 \%$ ).

Jak wynika z powyższej charakterystyki rdzeni i półsurowca mają one bardzo jednolity charakter świadczący o zwartości i technologicznej jednorodności całego inwentarza.

Wśród narzędzi bardzo liczna jest silnie morfologicznie zróżnicowana grupa rylców licząca 37 okazów $^{2}$ (21,8\% wszystkich form retuszowanych); są to rylce węgłowe boczne uformowane z odłupków lub wiórów, pojedyncze lub podwójne, czasem zwielokrotnione (9 szt.; ryc. 22: 2, 3, 6; ryc. 23: 1, 2). Ponadto wyróżniono rylce klinowe środkowe i boczne (5 szt.; ryc. 22: 1, 4, 5; ryc. 24: 3, 4), głównie wiórowych oraz wiórowe i wiórkowe rylce-łamańce (21 szt.; ryc. 23: 6; ryc. 24: 8). Na ogół są to formy wąskowierzchołkowe, często formowane z dystalnych fragmentów wiórów. Na uwagę zasługują rylce $\mathrm{z}$ wierzchołkiem uformowanym na piętce półsurowiaka typu Corbiac (ryc. 22: 4, 5; ryc. 23: 2, 4-6; ryc. 24: 5, 6), ponadto masywny rylec rdzeniokształtny o nakopalnianym charakterze oraz rylce klinowe boczne, których wierzchołek został uformowany przez specyficzny, wklęsły negatyw (ryc. 24: 1, 8). Wśród 27 rylczaków większość pochodzi z formowania rylców węglowych. Duża liczba rylców i rylczaków może mieć związek z intensywną obróbką kości zwierzęcych. Z narzędzi rylcopodobnych, brak w analizowanym inwentarzu typowych noży typu Kostionki, chociaż występują formy, które można uznać za ich półwytwory bądź atypowe noże (6 szt.).

Drapacze - 14 sztuk - tworzą nieliczną grupę wyróżniającą się sporym zróżnicowaniem morfologicznym, co pozwala na wyodrębnienie kilku typów. Najliczniejsze są klasyczne formy o drapiskach łukowych, stromych lub pół-

${ }^{2}$ Narzędzi tych jest 2,5 razy więcej niż drapaczy. 

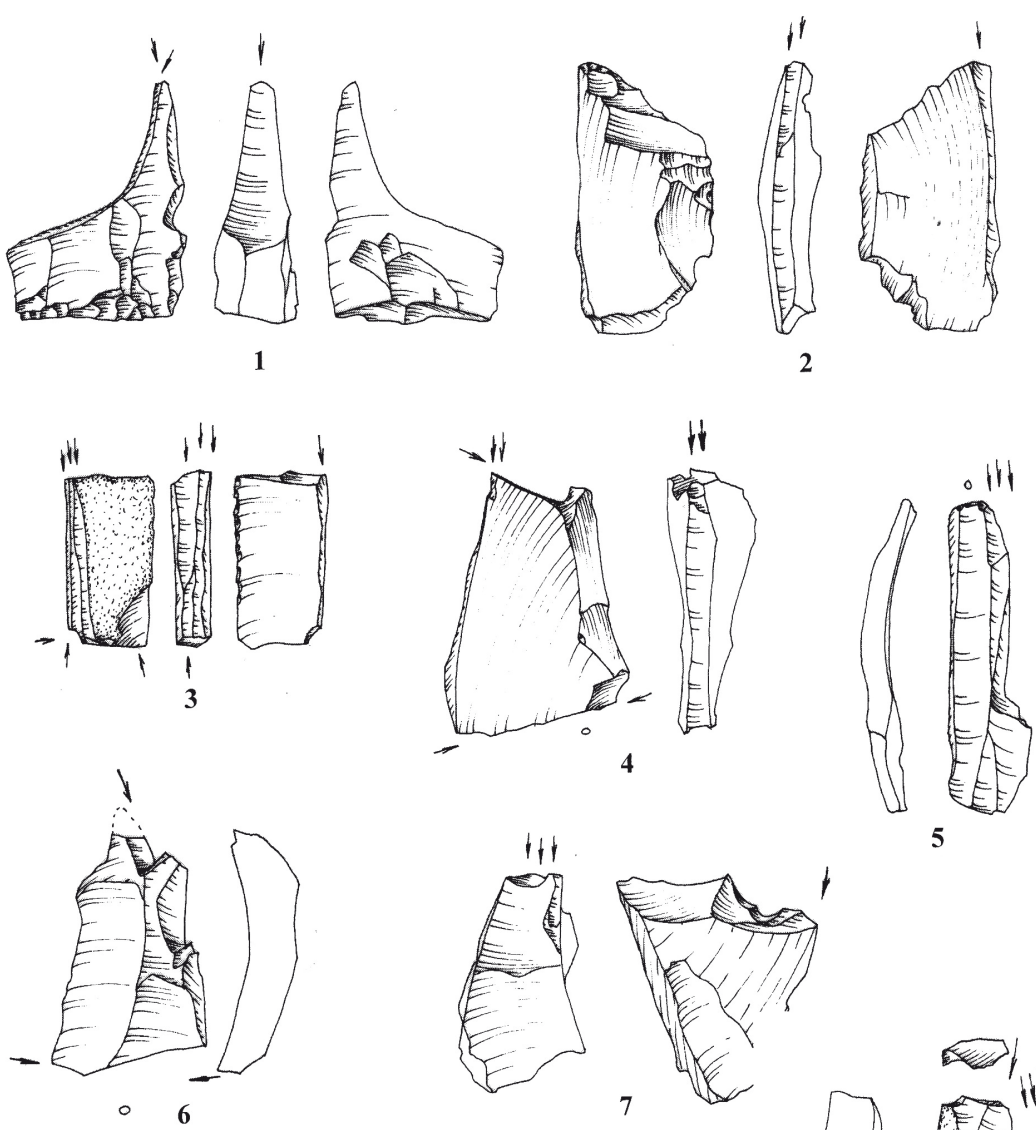

5
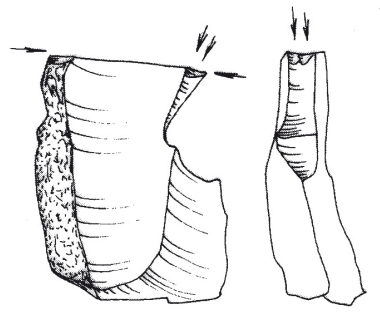

8
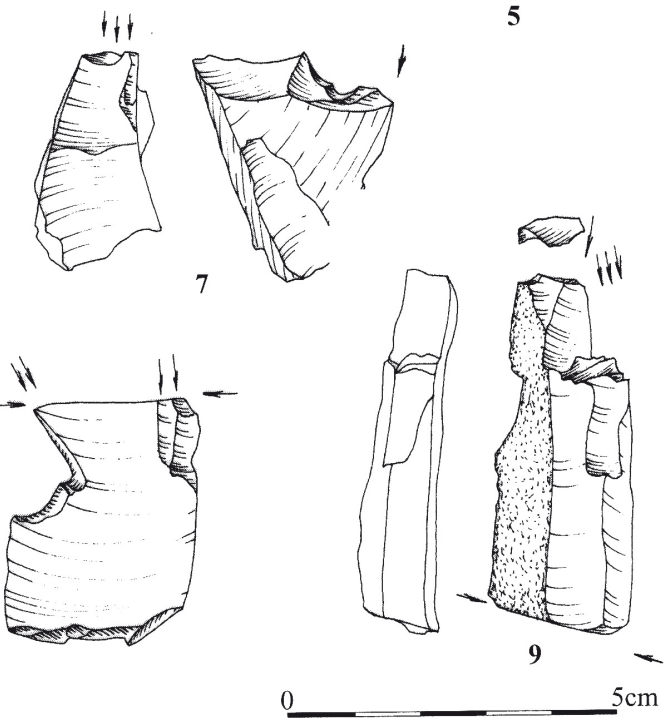

Ryc. 22. Halicz, Ukraina, stanowisko I. Wyroby krzemienne - rylce (rys. M. Sudoł) Fig. 22. Halych, Ukraine, site I. Flint artefacts - burins (drawing by M. Sudoł)

stromych usytuowanych w wierzchołkowych partiach wiórów (8 szt.; ryc. 25 : 1-3, 7, 8, ryc. 26: 1), ponadto wyróżniono egzemplarze kombinowane z rylcami (2 szt.; ryc. 25: 4, 5). Jeden drapacz ma półstromy retusz boku (ryc. 25: 6), oraz negatywy po dwustronnych odbiciach ścieniających podstawę i formu- 

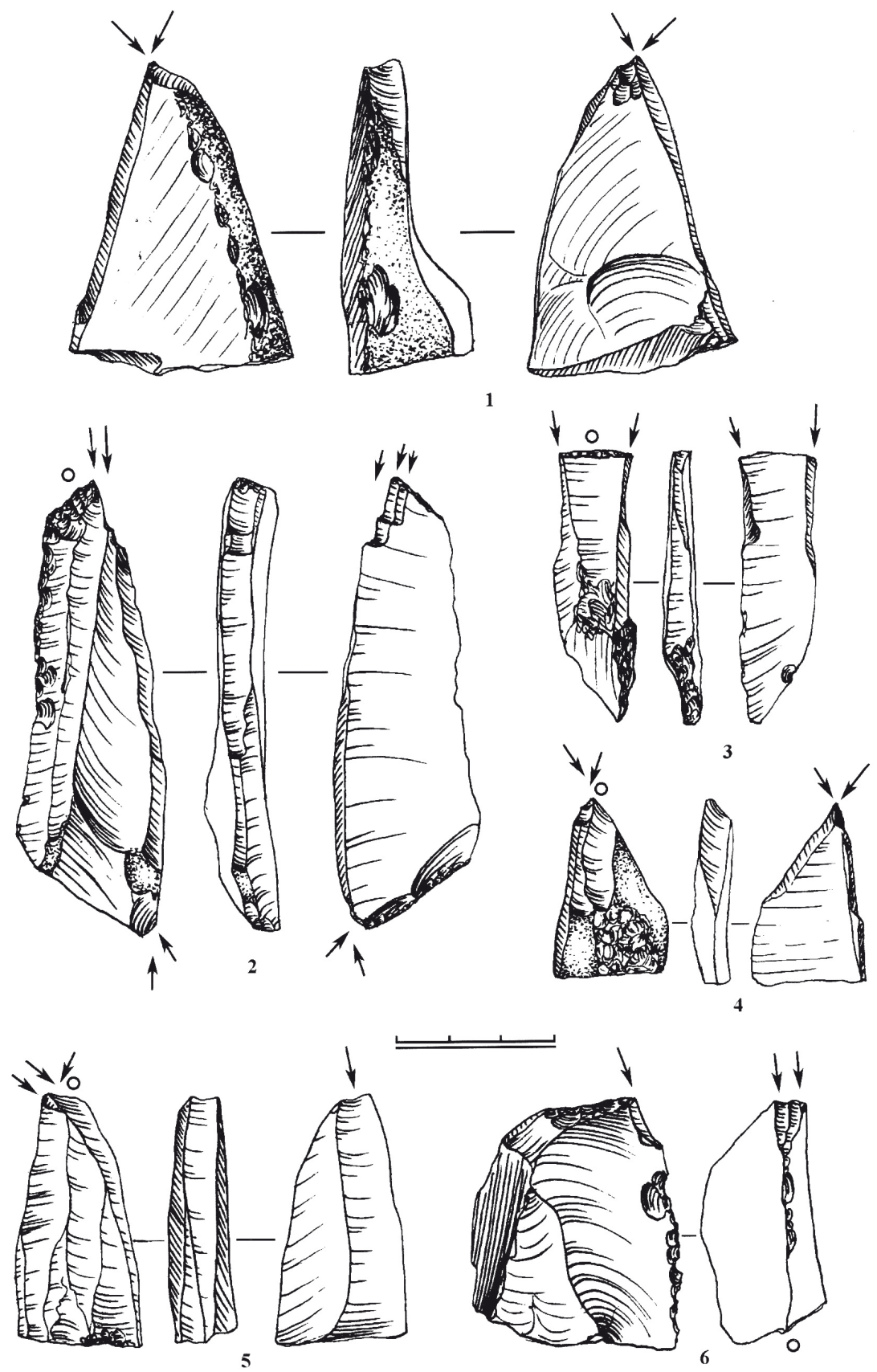

Ryc. 23. Halicz, Ukraina, stanowisko I. Wyroby krzemienne - rylce (rys. M. Sudoł) Fig. 23. Halych, Ukraine, site I. Flint artefacts - burins (drawing by M. Sudoł) 

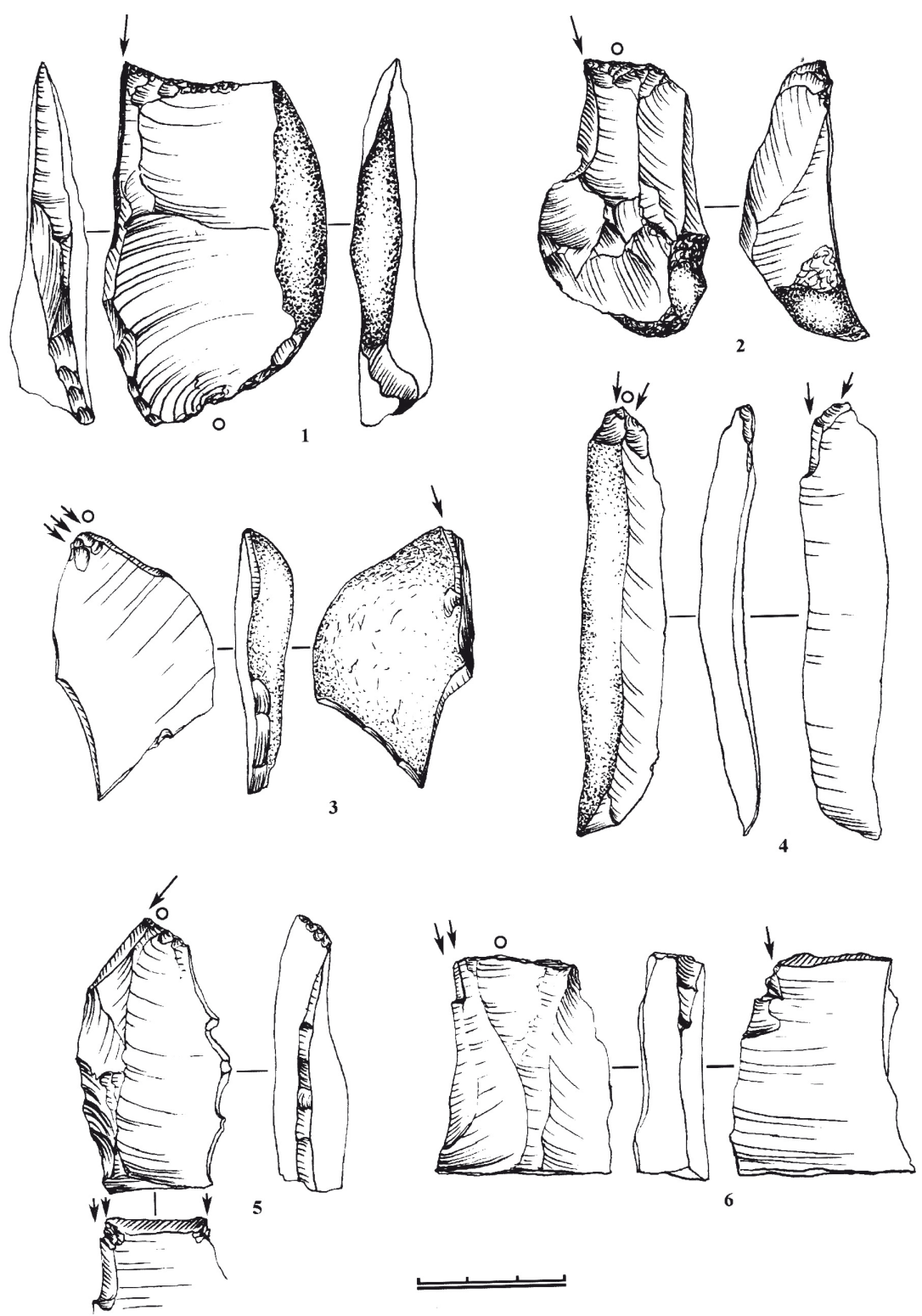

Ryc. 24. Halicz, Ukraina, stanowisko I. Wyroby krzemienne - rylce (rys. M. Sudoł) Fig. 24. Halych, Ukraine, site I. Flint artefacts - burins (drawing by M. Sudoł)

jących rodzaj „rękojeści” okazu, która być może umożliwiała obsadzenie go w oprawie. Kolejny typ drapaczy to formy o niskich, półstromych i zakolonych na jeden $\mathrm{z}$ boków drapiskach, usytuowanych na nieskróconym wierzchołku wióra (5 szt.; ryc. 26: 2-7), wśród nich są okazy masywne (ryc. 26: 2-4) 
oraz bardzo delikatne (ryc. 26: 5-7). Wyróżniono także jedyny odłupkowy egzemplarz o niskim, półstromym i prostym drapisku. Niemal wszystkie drapacze mają wiórowy lub wiórkowy charakter, z drapiskami zawsze usytuowanymi w wierzchołkowej części półsurowiaka. Nieliczną grupę (7 szt.) tworzą także półtylczaki poprzeczne lub skośne. Wydzielono tylko siedem okazów wykonanych z przełamanych wiórów lub wiórków.

Najliczniejszą kategorię wśród narzędzi stanowią, silnie zróżnicowane, mikrolityczne formy tylcowe (54 szt., 31,7\% wszystkich narzędzi; ryc. 26, 27). Bardzo charakterystyczne są tu mikroostrza graweckie (mikrograwety - 17 szt.), wykonane z rylczaków lub trójkątnych w przekroju poprzecznym wiórków, o dwustronnym stromym retuszu prostego tylca na krawędzi półsurowiaka (ryc. 27: 1, 5, 11, 13; ryc. 28: 5, 7, 17). Formy te są zawsze złamane przy podstawie i mają symetryczne bądź asymetryczne ostrze, czasem uformowane za pomocą zabiegu mikrorylcowego. Morfologicznie bliskie mikrograwetom są wiórki tylcowe o retuszu formującym tylec (6 szt.), zwężającym pierwotną szerokość wiórka aż do połowy, często dwustronnie złamane (ryc. 27: 2, 4, 6, 10; ryc. 28: 1-3). Wyróżniono też mikrotylczaki z zadziorem i wnęką (3 szt.; ryc. 27: 12, 19) oraz bardzo charakterystyczne ,igiełkowate” mikrotylczaki dwustronnie złamane o stromym i wysokim tylcu redukującym do połowy szerokość wiórka (4 szt.; ryc. 27: 7; ryc. 28: 1, 2). Pokaźną grupę stanowią półwytwory opisanych wyżej form tylcowych oraz powstałe podczas ich formowania odpadki (ryc. 27: 8, 14; ryc. 28: 8, 9, 15, 16, 19-25); są to fragmenty wiórków z mikrozałuskanymi wnękami lub ze skośnymi negatywami w miejscu złamania. Do opisanych powyżej wyrobów nawiązują nieco fragmenty wiórów i wiórków z mikroretuszem krawędzi przy piętce bądź przy wierzchołku; niektóre z nich przypominają formy liściakopodobne (ryc. 28: 18). Podsumowując tę kategorię wyrobów należy podkreślić ich zróżnicowane rozmiary - od mikroskopijnych $(7 \times 2 \mathrm{~mm})$ do zdecydowanie większych $(30 \times 8 \mathrm{~mm})$. Jednak znaczący udział mikrograwetów i mikrotylczaków nawiązuje do najstarszych zespołów naddniestrzańskiego grawetienu oraz do morawskiego pavlovienu.

Znaczącą grupę stanowią załuskane na krawędziach wióry (36 szt., 21,1\%), z przewagą retuszu półstromego i nieciągłego (ryc. 29: 1-4). Przeważnie są to masywne formy negatywowe, natomiast brak w inwentarzu typowych wiórowców. Do rzadkich okazów należą natomiast retuszowane odłupki (4 szt., 2,4\%). Ponadto w inwentarzu znalazło się zgrzebło, przekłuwacz oraz wiertnik. 

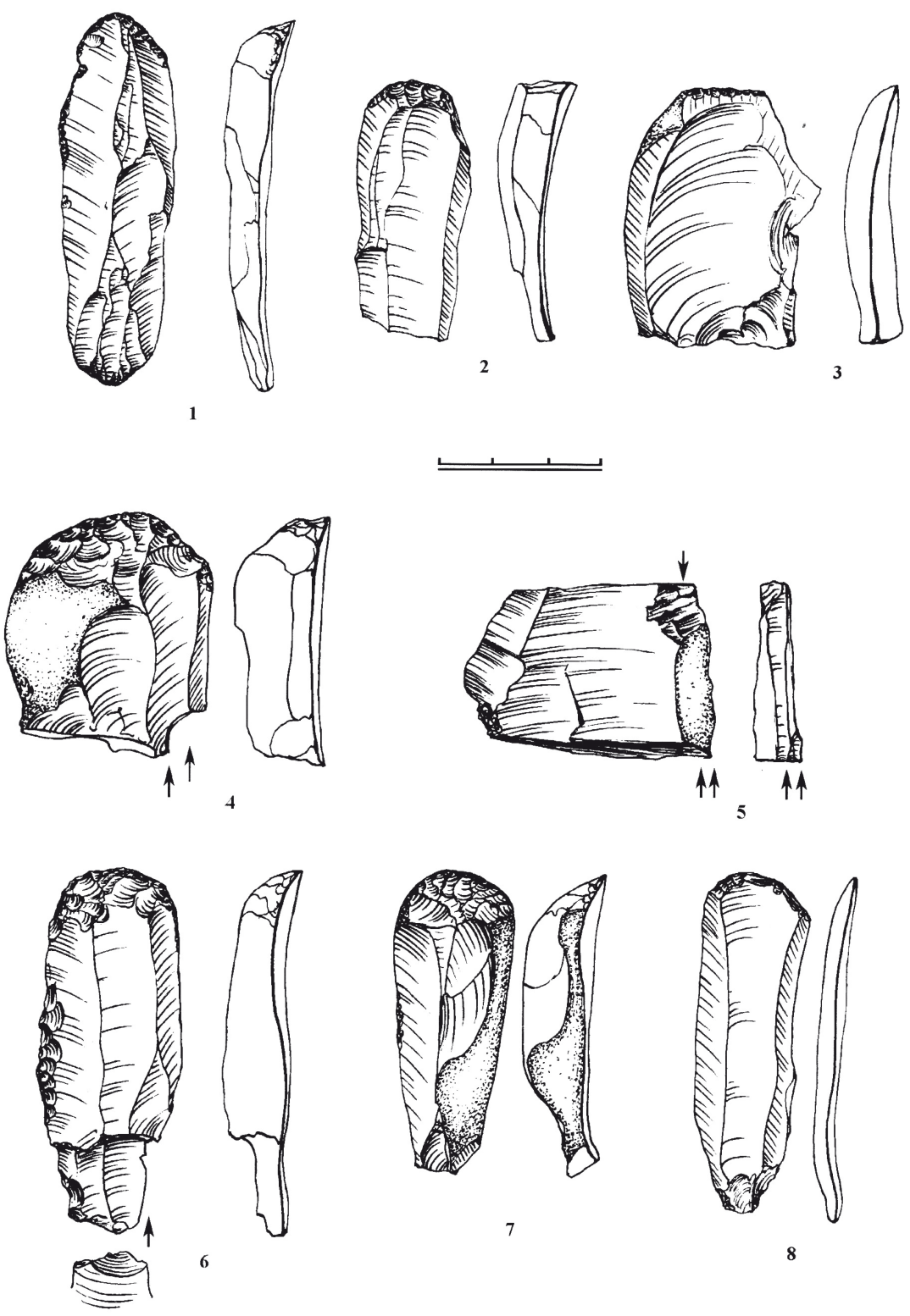

Ryc. 25. Halicz, Ukraina, stanowisko I. Wyroby krzemienne - drapacze (rys. M. Sudoł)

Fig. 25. Halych, Ukraine, site I. Flint artefacts - end-scrapers (drawing by M. Sudoł)

W grupie wyrobów retuszowanych wyróżniają się dwie metryczne (wielkościowe) ich kategorie: makronarzędzia ( $>4$ cm długości) i mikronarzędzia (<3 cm długości). 
[38]
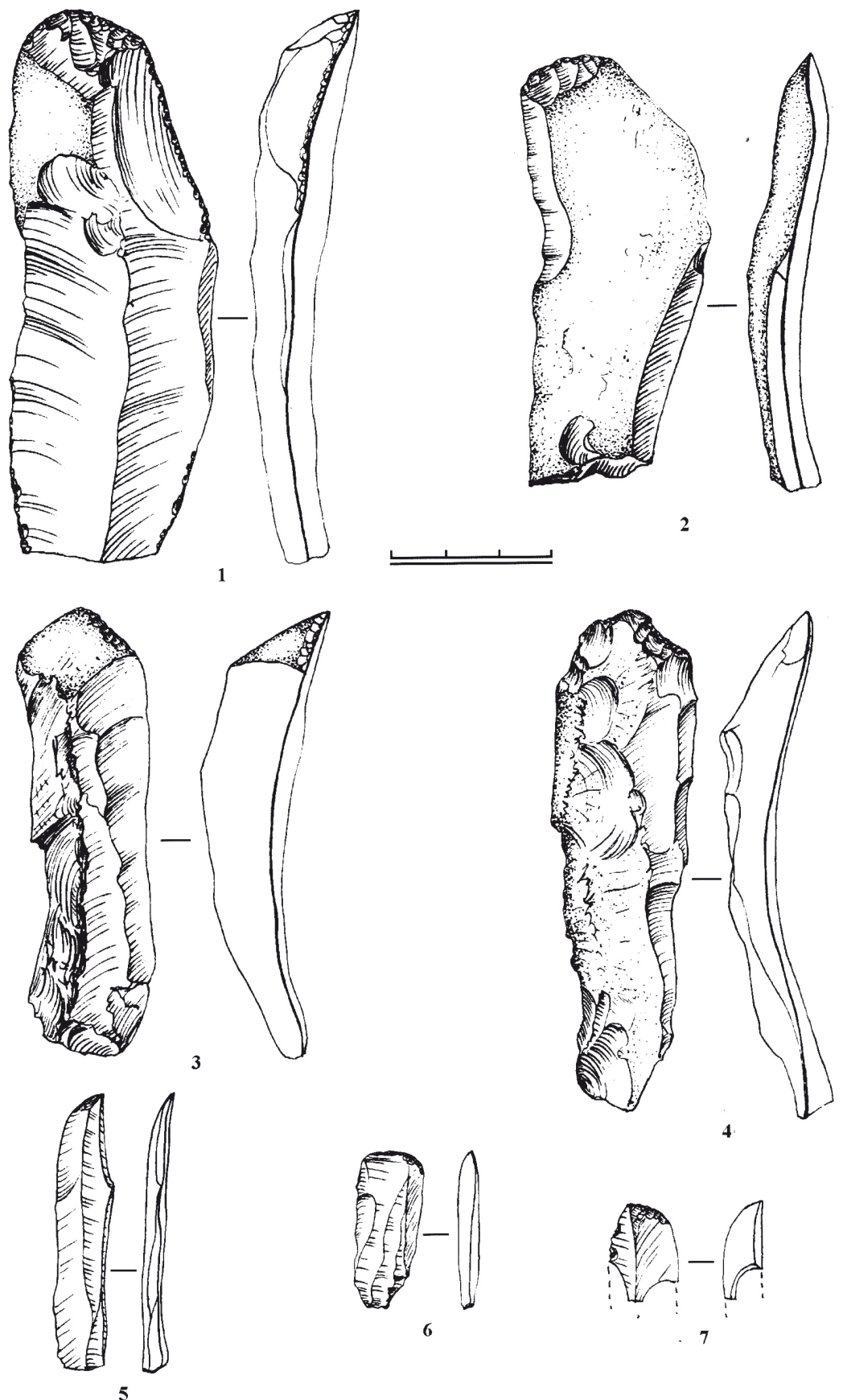

Ryc. 26. Halicz, Ukraina, stanowisko I. Wyroby krzemienne - drapacze (rys. M. Sudoł)

Fig. 26. Halych, Ukraine, site I. Flint artefacts - end-scrapers (drawing by M. Sudoł) 

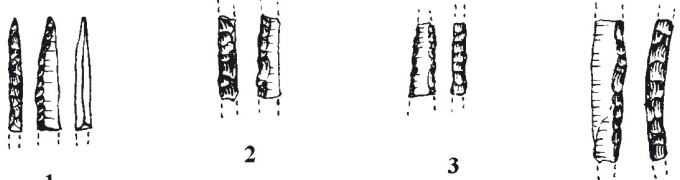

(1)

1

2

3

4
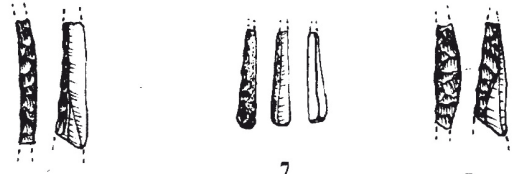

MA

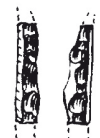

8

9

10
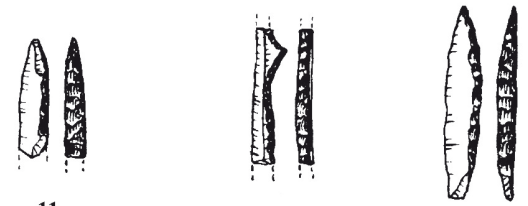

13

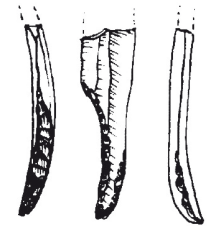

12
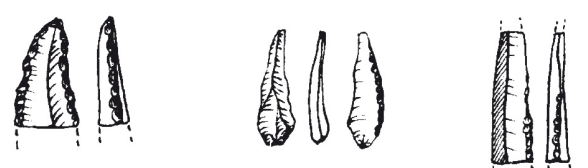

16
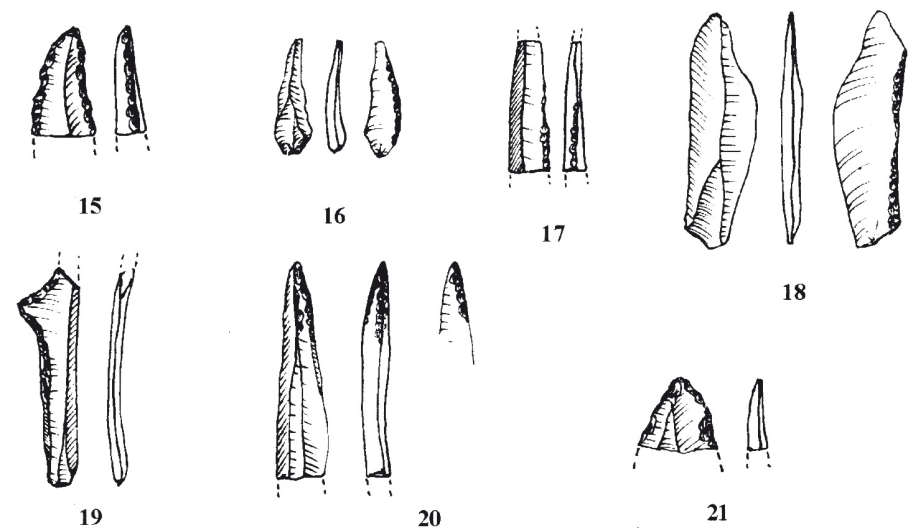

17
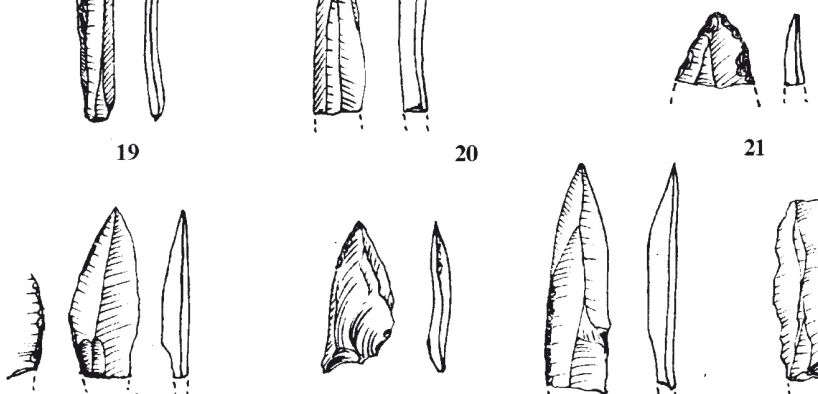

22
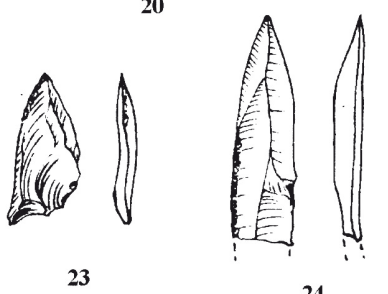

21

24
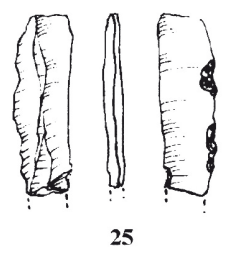

Ryc. 27. Halicz, Ukraina, stanowisko I. Wyroby krzemienne - mikrotylczaki i ich półwytwory (rys. M. Sudoł)

Fig. 27. Halych, Ukraine, site I. Flint artefacts - micro-truncated pieces and their semi-products (drawing by M. Sudoł) 


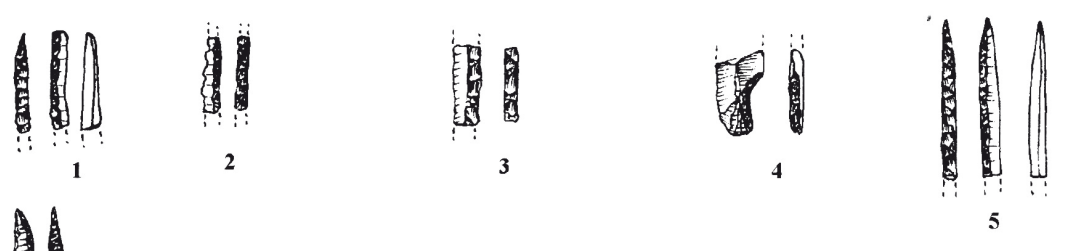

賞
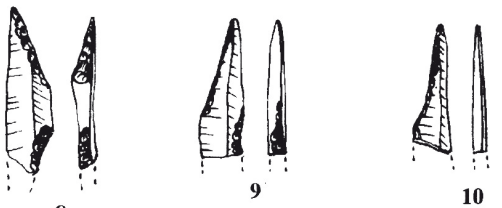

10
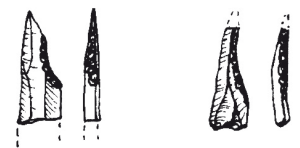

12

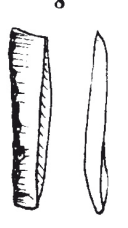

14

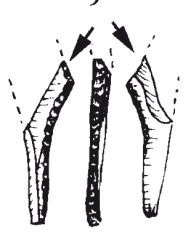

15

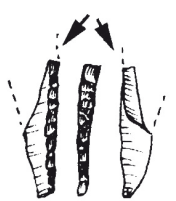

16
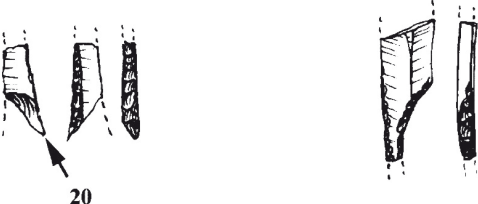

21

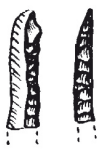

17

13
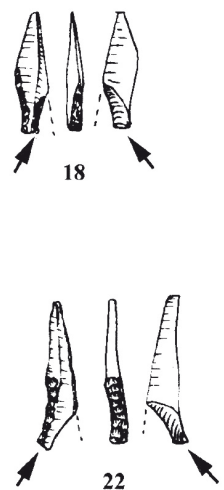

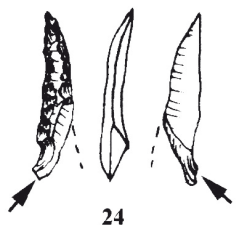

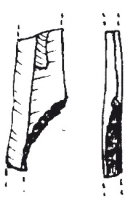

25

Ryc. 28. Halicz, Ukraina, stanowisko I. Wyroby krzemienne - mikrotylczaki i ich półwytwory (rys. M. Sudoł)

Fig. 28. Halych, Ukraine, site I. Flint artefacts - micro-truncated pieces and their semi-products (drawing by M. Sudoł)

\section{Analiza porównawcza wyrobów krzemiennych}

Rozpatrując inwentarz krzemienny z Halicza na tle innych podobnych pod względem chronologiczno-kulturowym, należy wymienić najbliżej położone, na przeciwległym brzegu Dniestru, stanowiska w Meżygircach I (ryc. 30). Z badań w latach 1976-1977 i 1980-1990 pozyskano zbiór liczący 

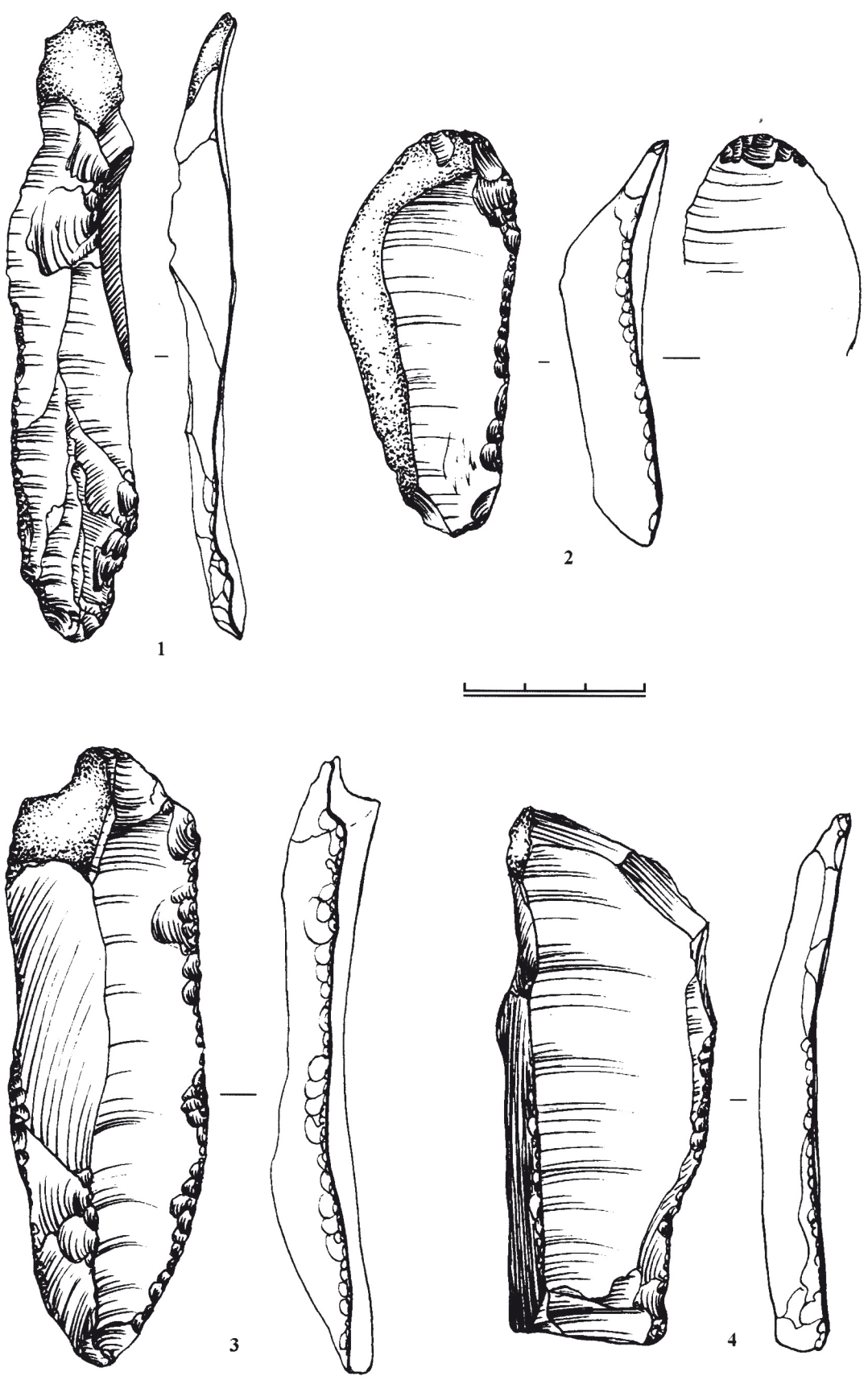

Ryc. 29. Halicz, Ukraina, stanowisko I. Wyroby krzemienne - wióry retuszowane (rys. M. Sudoł)

Fig. 29. Halych, Ukraine, site I. Flint artefacts - retouched blades (drawing by M. Sudol) 
ponad 15000 okazów krzemiennych, który przez odkrywców został zaliczony do kultury mołodowskiej, rozumianej jako naddniestrzański wariant kompleksu graweckiego (Grigoriewa, Kłapczuk 1981, s. 58, 59; Koulakovska, Otte 1999, s. 149-166). Poza wyrobami krzemiennymi znaleziono także 500 fragmentów kości, jednak inaczej niż w Haliczu najwięcej było tu szczątków renifera, mniej zaś mamuta, konia, niedźwiedzia brunatnego, wilka i lisa. $\mathrm{Na}$ przebadanej powierzchni ponad $500 \mathrm{~m}^{2}$ odsłonięto kilkanaście palenisk, towarzyszące im przepalone kości i wyroby krzemienne, w większości tworzące koncentracje. Warstwa kulturowa, w obrębie której wydzielono dwa horyzonty, była nienaruszona i zalegała w późnoplejstoceńskim, rowieńskim poziomie glebowym (Łanczont, Boguckij 2002, s. 80-83). Dla stanowiska w Meżygircach uzyskano trzy datowania radiowęglowe zawierające się między 17200 a 20300 lat p.n.e. (Koulakovska, Otte 1999, s. 150). W inwentarzu krzemiennym przeważają wióry i wiórki, uzyskiwane z jedno- i dwupiętowych rdzeni pryzmatycznych. Podobnie jak w Haliczu występuje metryczne zróżnicowanie narzędzi, a wśród mikrolitycznych przeważają podobne formy tylcowe. Zauważalną różnicą jest obecność kilku wiórowych ostrzy graweckich. Tak jak w Haliczu wśród narzędzi najliczniejsze są rylce, niewielką zaś grupę tworzą drapacze, natomiast znaleziono kilka, nieobecnych w Haliczu, narzędzi bifacjalnych. Porównanie stanowisk w Haliczu i Meżygircach można ująć następująco:

1. Oba stanowiska położone są na najwyższych punktach prawego i lewego brzegu doliny Dniestru, w tej samej strefie krajobrazowej.

2. Oba stanowiska geologicznie są związane z poziomem rowieńskiej gleby kopalnej, z tym, że warstwa kulturowa w Haliczu zalegała nieco poniżej tego poziomu, co sugeruje jego starszy wiek od stanowiska w Meżygircach.

3. Zgodnie $\mathrm{z}$ datowaniem radiowęglowym dwukrotne zasiedlenie terenu stanowiska w Meżygircach należy datować od 20 do 17 tysięcy lat temu, natomiast trzykrotne zasiedlenie terenu stanowiska w Haliczu miało miejsce między 25 a 19 tysięcy lat temu.

4. Planigrafia obu stanowisk jest podobna i charakteryzuje się obecnością palenisk, krzemienic oraz koncentracji kości zwierzęcych, liczniejszych jednak w Meżygircach. W przypadku Halicza są to niemal wyłącznie kości mamuta, w Mieżygircach zaś różnych gatunków z przewagą szczątków renifera.

5. Stan zachowania zarówno kości, jak i wyrobów krzemiennych jest wyraźnie lepszy w Haliczu, natomiast w Meżygircach kości - w przeciwieństwie do wyrobów krzemiennych - mają ślady zagładzenia sugerujące ich podepozycyjne przemieszczenie. 


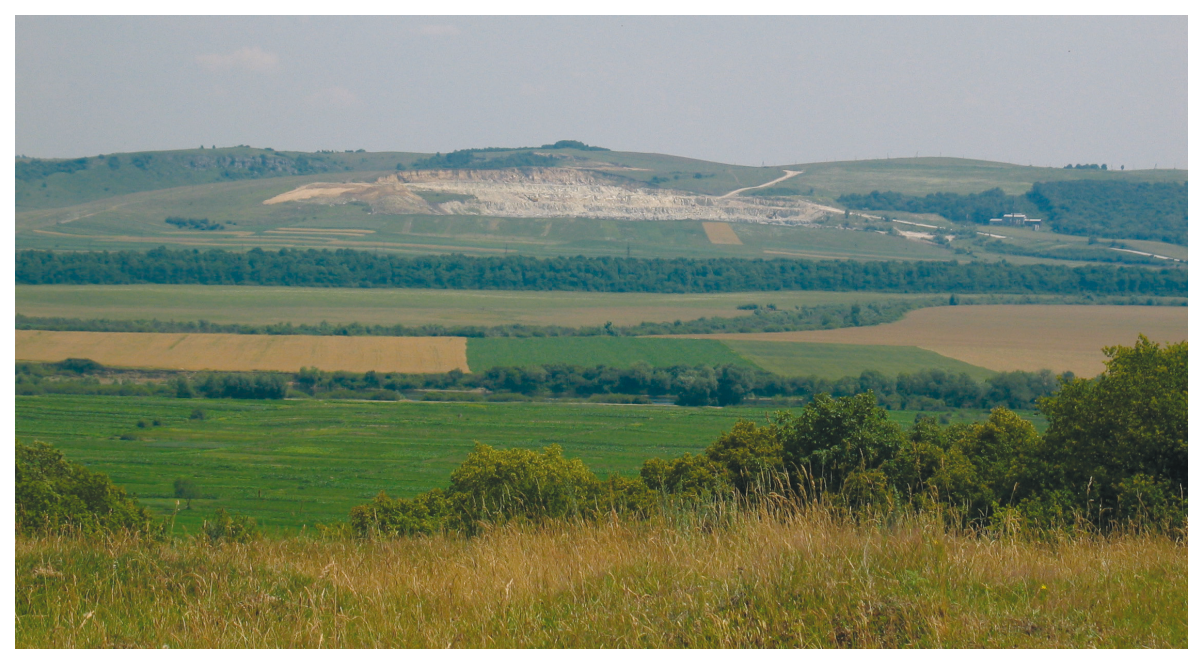

Ryc. 30. Halicz, Ukraina, stanowisko I. Widok na stanowisko w Meżygircach (fot. K. Cyrek)

Fig. 30. Halych, Ukraine, site I. View of the archaeological site in Meżygirce (phot. by K. Cyrek)

6. Technika obróbki krzemienia jest analogiczna na obu stanowiskach i głównym jej celem było otrzymanie wiórów i wiórków, z których następnie wykonywano narzędzia. Różnicą jest wyraźnie większe znaczenie wiórów niż wiórków w przypadku inwentarza z Meżygircy.

7. Oblicze typologiczne obu inwentarzy jest podobne - przeważają rylce nad drapaczami oraz znaczący jest udział form tylcowych; wyjątek stanowi obecności w Meżygircach wyrobów dwustronnych w postaci zgrzebła i dwóch ostrzy. Wśród mikrotylczaków brak w Meżygircach form ,igiełkowatych" oraz z zadziorem, które są obecne w Haliczu.

8. W Meżygircach znaleziono fragment ostrza kościanego, jakiego brak w Haliczu.

Podsumowując powyższe porównanie, należy przyjąć, że charakter kulturowy obu stanowisk jest taki sam; pozyskane inwentarze krzemienne można zaliczyć do „mołodowskiej” (Rogaczow, Anikowicz 1984) lub do „środkowodniestrzańskiej' (Borzjak 1998) tradycji kulturowej. Jednak zwraca uwage ich odmienny, łowiecko-funkcjonalny charakter. Jeśli stanowisko w Haliczu możemy interpretować jako pozostałość wielokrotnych sezonowych obozowisk łowieckich (,butchering sites”), gdzie niemal wyłącznym obiektem polowań były mamuty, to Meżygircy bardziej przypomina dłużej zamieszkiwane obozowisko podstawowe (,,base camp”) z pozostałościami polowań na zróżnicowaną gatunkowo faunę. 
W tym miejscu należy poświęcić kilka słów zagadnieniu „kultury mołodowskiej”. Po raz pierwszy kultura grawecka została zidentyfikowana na obszarze Naddniestrza pod koniec lat 50. ubiegłego wieku, dzięki badaniom O. Czernysza (1959) na stanowisku Mołodowa V (VII i VIII warstwa). Materiały krzemienne $\mathrm{z}$ tych poziomów przyporządkował on do III grupy górnopaleolitycznych inwentarzy Naddniestrza z analogiami między innymi w Gagarino, Kostionkach I (górny poziom), Borszewo I, Awdiejewo, Pavlov, Petrkovice, Willendorf, Dolne Vestonice czy Predmost (Czernysz 1959). Uważając, że inni badacze niesłusznie określali je mianem graweckich, O. Czernysz wszystkie te zespoły zaliczył najpierw do madleńskiej (Czernysz 1959), a później do solutrejskiej (Czernysz 1961) tradycji kulturowej. Swój pogląd argumentował niedostatecznie dokładną definicją grawetienu i jego nadmiernie ,rozciagliwym”, zarówno w aspekcie chronologicznym jak i terytorialnym, pojmowaniem przez innych badaczy (Czernysz 1987). Zdaniem autorów niniejszego artykułu graweckie cechy w górnym paleolicie doliny Dniestru są widoczne już w najstarszych poziomach stanowiska Mołodowa V, na przykład poziomu X. Niewykluczone, że pochodzący z niego inwentarz stanowi mechaniczną mieszaninę lub też jest efektem wzajemnych oddziaływań trzech głównych tradycji kulturowych pierwszej połowy górnego paleolitu (oryniaku, szeletienu i grawetienu). Taki zróżnicowany kulturowo obraz najstarszej fazy górnego paleolitu Naddniestrza usprawiedliwia pogląd o jego związkach z ,oryniacko-solutrejsko-grawecko-perigordzkim okresem” jak to ujmował O. Czernysz (1987). Kompromisową propozycją, wydaje się być wysunięte przez G. Grigoriewa pojęcie „,kultury mołodowskiej” (Grigoriew 1970), rozwinięte później przez A. Rogaczewa i M. Anikowicza (1984, s. 162-271) i dotyczące treści kulturowych odkrytych w poziomach od X do VII na stanowisku Mołodowa V oraz innych analogicznych zespołów z obszaru Naddniestrza datowanych od 29 do 23 tysięcy lat temu. Wymienieni autorzy podają najbardziej charakterystyczne cechy kultury mołodowskiej:

- technika pryzmatycznego rdzenia wiórowego,

- większość narzędzi wykonana z masywnych wiórów,

- zawsze obecna nieliczna grupa charakterystycznych mikrotylczaków,

- znacząca rola techniki rylcowej,

- obecność pojedynczych, dwustronnych ostrzy, noży typu Kostionki, wysokich drapaczy i ostrzy z zadziorem, których obecność jest najczęściej interpretowana jako efekt międzykulturowych kontaktów.

Poczynając od warstwy VII na stanowisku w Mołodowej V wspomniani badacze wydzielają późną fazę kultury mołodowskiej, charakteryzującą się 
szczególnie licznym udziałem wyrobów kościanych i form tylcowych (Rogaczow, Anikowicz 1984).

W związku z obecnością na „mołodowskich” stanowiskach reliktów zróżnicowanej gatunkowo plejstoceńskiej fauny pojawiły się koncepcje na temat przewagi bądź nawet dominacji w polowaniach na określone gatunki zwierząt, w zależności od krajobrazowo-klimatycznej strefy. Jedna z nich dotyczyła specjalizacji łowieckiej - w strefie peryglacjalnego lasostepu polowano na mamuty, na obszarze stepu - na bizony i konie, w strefie przejściowej zaś, jaką była dolina Dniestru - na renifery (Anikowicz 1999). Teza o „reniferowym" charakterze górnego paleolitu Naddniestrza została powszechnie zaakceptowana, również dzięki bogatym znaleziskom faunistycznym z Meżygirców i mołdawskich stanowisk z międzyrzecza Dniestru i Prutu - Mitoc-Malu Galben (Chirica 1989) czy Cosaoutsi (Borzjak 1993, s. 331-336). Do tej koncepcji nie pasuje jednak stanowisko w Haliczu, na którym odnotowano wyraźną przewagę kości mamuta, chociaż należy pamiętać, że zostało ono przebadane tylko częściowo. Tym niemniej, jeśli zestawimy obecność i liczbę osobników poszczególnych gatunków ssaków łownych na trzech najważniejszych stanowiskach Naddniestrza, przedstawiona powyżej „reniferowa” koncepcja nie jest już tak przekonywująca (tab. 2). Poza tym uwzględniając przeciętną ilość mięsa jaką można było uzyskać z poszczególnych zwierząt, okazuje się, że masa mięsna jednego mamuta była porównywalna $\mathrm{z}$ tuszami mięsnymi 12 reniferów. Dlatego nie można uważać graweckiego epizodu w paleolicie Naddniestrza za okres specjalizacji w polowaniach na renifera. Przeciwnie, należy przyjąć zróżnicowany gatunkowo charakter gospodarki łowieckiej ówczesnej społeczności.

Stanowiska z rejonu Dniestru i Prutu I. Borziak (1998) zalicza do ,karpacko-dniestrzańskiego grawetu", natomiast - jego zdaniem - do typowo graweckiego kompleksu należą zespoły z ostrzami z zadziorem (jednozadziorce), takie jak Willendorf warstwa 9, Kraków-ul. Spadzista, Kostionki I, warstwa 1, Awdiejewo, Chotylewo i Zarańsk. Inwentarze znad Prutu i Dniestru wyróżniają się większą masywnością wyrobów (Borziak 1998). Do wczesnej fazy grawetienu Naddniestrza I. Borziak zalicza Mitoc-Malu Galben (warstwy 1-4), Mołodową V (warstwy 7-10), Czutuleszti i inne. Charakterystyczną cechą tych inwentarzy są drapacze na masywnych wiórach, rylce boczne, wiórki tylcowe i ostrza ,igiełkowate”. Według wspomnianego badacza do rozwiniętego grawetienu należą Mołodowa V (warstwy VI-I), Korman IV (warstwy 7-1), Cosaoutsi (warstwy 1-10) oraz Ataki I-II; okres ten charakteryzuje większa mikrolityzacja wyrobów. Wydawało się, że w ra- 
mach powyższego podziału inwentarz warstwy VII z Mołodowej V ma przejściowy (mikrolityczno-makrolityczny) charakter. Jednak powtórne badania na stanowisku, przeprowadzone w latach 1998-1999, wykazały, że warstwa VII powstała w wyniku kilku faz zasiedlenia stanowiska w okresie od 25 do 23 tysięcy lat temu (Haesaerts i in. 2004, s. 33-56). Należy przyjąć, że stanowiska Mołodowa V, Mitoc-Malu Galben i Cosoutsi tworzą chronostratygraficzny schemat naddniestrzańskiej sekwencji grawetienu i epigrawetienu od 33 do 13 tysięcy lat temu, z wyraźnymi nawiązaniami do willendorfsko-pavlowskiej i kostienkowsko-awdiejewskiej tradycji kulturowej w środkowej i wschodniej Europie (Otte, Noiret, Chirica 1996, s. 213-226; Damblonn i in. 1997, s. 1-10).

Tabela 2. Udział liczbowy dużych i średnich ssaków w Mołodowej V, warstwy V-IX (MV/V-IX), Meżygircach I (MI) i Haliczu I (HI)

\begin{tabular}{|c|c|c|c|c|c|c|c|}
\hline Zwierzęta & $\sum$ & $\sum_{z}^{\sum}$ & $\sum_{z}^{z}$ & $\sum_{\sum}^{\equiv}$ & $\underset{z}{\Sigma}$ & $\bar{\Sigma}$ & $\Xi$ \\
\hline $\begin{array}{l}\text { Mamut } \\
\text { (Elephas primigenius) }\end{array}$ & 2 & 4 & 6 & 2 & 2 & + & 5 \\
\hline $\begin{array}{l}\text { Renifer } \\
\text { (Rangifer tarandus) }\end{array}$ & 11 & 14 & 12 & 3 & 5 & + & 1 \\
\hline $\begin{array}{l}\text { Koń } \\
\text { (Equus equus) }\end{array}$ & 4 & 6 & 10 & 3 & 5 & + & ? \\
\hline $\begin{array}{l}\text { Żubr } \\
\text { (Bison priscus) }\end{array}$ & - & 1 & 1 & - & 2 & $?$ & - \\
\hline $\begin{array}{l}\text { Nosorożec } \\
\text { (Rhinoceros antiquitatis) }\end{array}$ & - & 1 & 1 & - & 1 & $?$ & - \\
\hline
\end{tabular}

W ostatnich latach wielokrotnie podejmowano dyskusję dotyczącą ,naddniestrzańskiego" i ,wschodnioeuropejskiego grawetienu” (Otte, Noiret, Chirica 1996, s. 213-226; Anikowicz 1998, s. 35-66; Borziak 1998, s. 135-141; Borziak, Kulakowska 1998, s. 55-64; Kozłowski 2002; 2004). Na pytanie o pochodzenie wschodniograweckich zespołów najczęściej podaje się przypuszczenie o migracyjnym charakterze tego zjawiska. Jeszcze w latach 60. XX wieku sformułowano koncepcję willendorfsko-pavlovsko-kostionkowskiej wspólnoty kulturowej (Grigoriew 1970), która narodziła się w Europie Środkowej podczas ocieplenia Stielfried B (Paudorf), a do najstarszych stanowisk należą między innymi Willendorf i Petrkowice (Kozłowski, Kozłowski 1975). 
Nieco później uzyskano cały szereg datowań radiowęglowych, które pozwoliły zrekonstruować kierunek rozprzestrzenienia graweckich elementów właśnie z zachodu na wschód. Dzięki najstarszym datom uzyskanym dla stanowisk naddunajskich (Willendorf) i morawskich (Pavlov, Dolne Vestonice) (Svoboda 1994; Klima 1995) uznano, że właśnie w rejonie naddunajsko-morawskim narodziła się grawecka tradycja kulturowa z mamucią specjalizacją łowiecka, techniką pryzmatycznego wiórowego rdzenia i specyficznym inwentarzem narzędziowym, w którym główną rolę odgrywały jednozadziorce i noże typu Kostionki. Istotnym elementem ówczesnej kultury była twórczość artystyczna przejawiająca się między innymi w figurkach tzw. Wenus.

Jednak w inwentarzach z wczesnego „Pavlovienu” brak noży typu Kostienki i jednozadziorców, natomiast występują zróżnicowane ostrza graweckie i mikrotylczaki (Klima 1995, s. 131-136), co jest bardziej podobne do wczesnograweckich zespołów znad Dniestru, a mniej do tych znad Dniepru i Donu. Wiele wskazuje na to, że w okresie od 24 do 23 tysięcy lat temu rozpoczęły się przemieszczenia graweckiego osadnictwa znad górnego Dunaju, przez karpackie przełęcze na północ i północny-wschód (przez południową Polskę, Wołyń i Polesie nad Dniepr i Don). Inny kierunek migracji przebiegał na południowy wschód, w rejon górnego i środkowego Naddniestrza (Kozłowski 1998, s. 131-200). Prawdopodobną przyczyną tych migracji było wymieranie w środkowej Europie mamutów, stanowiących podstawowy element graweckiej gospodarki. Zmniejszenie populacji tych zwierząt i ich przemieszczanie się na północny wschód potwierdzają wyniki badań paleontologicznych (Soffer 1993). Również południowopolskie stanowiska z tego okresu (np. Kraków-ul. Spadzista A, B, C, D, F i Piekary) świadczą o migracji graweckich łowców mamutów (Sobczyk 1995). Szczególnie interesujące wyniki uzyskano podczas badań stanowiska Kraków-ul. Spadzista B (Escutenaire i in. 1999), z którego pochodzi inwentarz wykazujący przejściowy charakter między grawetienem znad górnego Dunaju a jego odpowiednikiem znad Dniepru i Donu. W materiałach krzemiennych z 6 warstwy tego stanowiska udział noży typu Kostionki i jednozadziorców jest większy niż w Pawlovie, ale mniejszy niż w I warstwie stanowiska w Kostionkach. Specyficzną cechą inwentarza z Krakowa-ul. Spadzista jest obecność w sektorze B bogatej, wielowarstwowej koncentracji kości mamuta, interpretowanej jako pozostałość wielokrotnego (sezonowego) zasiedlenia tego miejsca, w okresie od 24 do 15 tysięcy lat temu (datowania radiowęglowe). Nagromadzenie w jednym miejscu kości ponad 70 osobników mamuta K. Sobczyk interpretuje jako rezultat kilku jednoczesnych lub też krótko po sobie następujących 
zdarzeń - naturalnej śmierci zwierząt (np. w wyniku stresu głodowego) oraz polowań i padlinożerstwa (Sobczyk 1995, s. 128-136).

Oprócz Krakowa-ul. Spadzista C2 do Pavlovienu zaliczono jeszcze kilka stanowisk z południowej Polski - Wójcice, Cyprzanów, Domaszkowice, Dziadowa Skała czy Jaskinia Obłazowa, warstwa VIII (Kozłowski, Kozłowski 1996). Zespoły te, podobnie jak ich morawskie odpowiedniki, datowane są na okres od 29 do 23 tysięcy lat temu. Dalej na wschód, oprócz pojedynczego znaleziska z Przemyśla, ul. Słowackiego (Kozłowski 1992, s. 126-133) brak stanowisk graweckich, aż do rejonu górnego Naddniestrza z Haliczem i Meżygircami. Taka sytuacja zdaje się potwierdzać „migracyjną tezę” dotyczącą genezy naddniestrzańskiego grawetienu. Jednak wątpliwości pojawiają się, kiedy uwzględnimy najnowsze datowania radiowęglowe uzyskane dla najstarszych (IX i X) warstw kulturowych z Mołodowej V (Czernysz 1987; Haesaerts i in 2004, s. 33-56): Mołodowa V, warstwa IX - 29600 i 28150 lat temu; Mołodowa V, warstwa X - 32600, 30400, 28700 i 27700 lat temu.

Natomiast najstarsze daty z Willendorf i ze stanowisk morawskich zamykają się w analogicznym przedziale 32-28 tysięcy lat temu, co przemawia za jednoczesnym pojawieniem się ,protograwetienu” nad górnym Dunajem i nad Dniestrem. Zastanawiając się nad lokalną genezą wschodnioeuropejskiego grawetienu warto zwrócić uwagę na obecność w inwentarzu z warstwy X w Mołodowej V, obok elementów graweckich, również form o oryniackiej, a przede wszystkim szeleckiej stylistyce (Czernysz 1987). Mogłoby to wskazywać na charakter kulturowego podłoża takiej autochtonicznej genezy, tym bardziej, że właśnie między innymi kultura szelecka jest brana pod uwagę przy rozpatrywaniu początków grawetienu w Europie Środkowej (Kozłowski 2004, s. 443). Konsekwentnemu rozwojowi szeleckiego, a później graweckiego osadnictwa w dolinie Dniestru mogły sprzyjać szczególnie korzystne warunki środowiskowe, podkreślane w przyrodniczych opracowaniach tego regionu (Łanczont i in. 2002, s. 25). Potwierdzeniem tych optymalnych uwarunkowań doliny Dniestru w górnym plejstocenie są wielokrotne (do 20 razy) zasiedlenia takich stanowisk jak Mołodowa I i V, Korman IV czy Cosoutsi.

Podobnie wielofazowym stanowiskiem jest Halicz I; uzyskane dla niego trzema różnymi metodami datowania zdają się potwierdzać wielokrotne zasiedlenie tego miejsca (tab. 3-5). W wynikach analiz ${ }^{14} \mathrm{C}$ i TL zwraca uwage pewna niezgodność polegająca na niższych wartościach kilku dat termoluminescencyjnych odbiegających od dat radiowęglowych dla poszczególnych poziomów zasiedlenia stanowiska. Prawdopodobnie jednak okupacja sta- 
Tabela 3. Halicz I, Ukraina. Wyniki analiz radiowęglowych*

\begin{tabular}{|l|c|c|c|c|}
\hline Symbol i lokalizacja próbki & $\begin{array}{c}\text { Charakter } \\
\text { próbki }\end{array}$ & $\begin{array}{c}\text { Symbol } \\
\text { laborato- } \\
\text { rium } \\
\text { i numer } \\
\text { próbki }\end{array}$ & $\begin{array}{c}\text { Wiek }{ }^{14} \mathbf{C} \\
\text { (niekalibrowa- } \\
\text { ny, p.n.e.) }\end{array}$ & $\begin{array}{c}\text { Poziom zasiedle- } \\
\text { nia w obrębie I } \\
\text { warstwy kultu- } \\
\text { rowej }\end{array}$ \\
\hline Hlcz I/00; palenisko I & węgle & Ki-8928 & $25100 \pm 450$ & poziom Ic \\
\hline Hlcz I/00; 10/D & węgle & Ki-8929 & $24900 \pm 450$ & poziom Ic \\
\hline Hlcz I/00; palenisko II & węgle & Ki-8930 & $24600 \pm 450$ & poziom Ib \\
\hline Hlcz I/00; D/6 & kości & Ki-8931 & $24200 \pm 600$ & poziom Ib \\
\hline Hlcz I/00; A/4 & kości & Ki-8932 & $23500 \pm 600$ & poziom Ib(?) \\
\hline $\begin{array}{l}\text { Hlcz I/01, O/5; } \\
\text { V warstwa mechaniczna }\end{array}$ & węgle & Ki-10333 & $20550 \pm 400$ & poziom Ia \\
\hline $\begin{array}{l}\text { Hlcz I/01, O, N/5; } \\
\text { V warstwa mechaniczna }\end{array}$ & węgle & Ki-10334 & $19130 \pm 360$ & poziom Ia \\
\hline $\begin{array}{l}\text { Hlcz I/01, M/6; } \\
\text { V warstwa mechaniczna }\end{array}$ & węgle & Ki-10335 & $19460 \pm 400$ & poziom Ia \\
\hline $\begin{array}{l}\text { Hlcz I/01, N/4/5; } \\
\text { V warstwa mechaniczna }\end{array}$ & węgle & Ki-10404 & $18510 \pm 300$ & poziom Ia \\
\hline $\begin{array}{l}\text { Hlcz I/01, M/6; } \\
\text { V warstwa mechaniczna }\end{array}$ & węgle & Ki-10400 & $19460 \pm 400$ & poziom Ia \\
\hline
\end{tabular}

*Analizy zostały wykonane w Laboratorium Radioweglowym w Kijowie przez N. N. Kovaljuka.

nowiska została prawidłowo wydatowana metodą radiowęglową, młodsze daty uzyskane metodą termoluminescencyjną dotyczą lessu, który przykrył poziom kulturowy już po jego zdeponowaniu. Patyna tlenowa pokrywająca większość wyrobów krzemiennych może świadczyć o ich stosunkowo długim zaleganiu na powierzchni, zanim zostały przykryte nawianym lessem.

Datowanie metodą uranowo-torową okazało się interesujące, przede wszystkim z metodycznego punktu widzenia (Hercman, Gorka 2002). Wszystkie cztery próby zostały pobrane z jednej kości długiej mamuta, a uzyskane wyniki należy traktować jako wskaźnik minimalnego (EU) i maksymalnego (LU) wieku warstwy kulturowej, z której pochodziła analizowana kość, zatem w świetle metody uranowo-torowej jej wiek można oszacować w przedziale między 10 a 25 tysięcy lat p.n.e.

Uwzględniając powyższe datowania (przede wszystkim radiowęglowe) i korelując je z wynikami analizy mikrostratygraficznej, można przyjąć, że górnopaleolityczna (I) warstwa kulturowa w Haliczu ma trójfazowy charakter, przy czym najmłodszą fazę zasiedlenia (Ia) można datować między 19 
Tabela 4. Halicz I, Ukraina. Wyniki analiz termoluminescencyjnych*

\begin{tabular}{|c|c|c|c|c|c|}
\hline $\begin{array}{c}\text { Symbol } \\
\text { i lokalizacja } \\
\text { próbki }\end{array}$ & $\begin{array}{c}\text { Symbol la- } \\
\text { boratorium } \\
\text { i numer } \\
\text { próbki }\end{array}$ & $\begin{array}{l}\text { Dawka } \\
\text { roczna }\end{array}$ & $\begin{array}{c}\text { Dawka } \\
\text { geologiczna } \\
\text { ED [Gy] }\end{array}$ & $\begin{array}{c}\text { Wiek } \\
\text { [ka] }\end{array}$ & $\begin{array}{c}\text { Poziom } \\
\text { zasiedlenia } \\
\text { w obrębie } \\
\text { I warstwy } \\
\text { kulturowej }\end{array}$ \\
\hline $\begin{array}{l}\mathrm{HI}, \mathrm{P} / 5 ; \\
\text { V warstwa } \\
\text { mechaniczna }\end{array}$ & Lub-3982 & $2,787 \pm 0,31$ & $50 \pm 4,5$ & $17,9 \pm 2,6$ & poziom Ia \\
\hline $\begin{array}{l}\mathrm{HI}, \mathrm{O} / \mathrm{N} / 5 ; \\
\text { V warstwa } \\
\text { mechaniczna }\end{array}$ & Lub-3983 & $2,937 \pm 0,33$ & $59 \pm 6,5$ & $20,1 \pm 3$ & poziom Ia \\
\hline $\begin{array}{l}\mathrm{HI}, \mathrm{O} / 5 ; \\
\text { V warstwa } \\
\text { mechaniczna }\end{array}$ & Lub-3984 & $2,764 \pm 0,25$ & $50 \pm 5$ & $18,1 \pm 2,4$ & poziom Ia \\
\hline $\begin{array}{l}\text { HI, Ł/5; } \\
\text { V warstwa } \\
\text { mechaniczna }\end{array}$ & Lub-3985 & $2,881 \pm 0,23$ & $51 \pm 4$ & $17,7 \pm 2$ & Poziom Ia \\
\hline HIa, 3; $252 \mathrm{~cm}$ & UG-5632 & & & $20,8 \pm 2,91$ & poziom Ia \\
\hline $\begin{array}{l}\text { HIa, } 3 / 2 \\
252 \mathrm{~cm}\end{array}$ & UG-5633 & & & $20,0 \pm 2,95$ & poziom Ia \\
\hline HIc, 4; $290 \mathrm{~cm}$ & UG-5634 & & & $21,8 \pm 3,0$ & poziom Ic \\
\hline $\mathrm{H}, 5 ; 344 \mathrm{~cm}$ & UG-5635 & & & $26,4 \pm 4,0$ & $\begin{array}{c}\text { poniżej I } \\
\text { warstwy } \\
\text { kulturowej }\end{array}$ \\
\hline
\end{tabular}

*Analizy zostały wykonane w Laboratorium Uniwersytetu Marii Curie-Skłodowskiej w Lublinie przez J. Kusiaka oraz w Laboratorium Uniwersytetu Gdańskiego przez A. Bluszcza (Fedorowicz 2006).

a 21 tysiącleciem p.n.e., środkową (Ib) między 23 a 24 tysiącleciem p.n.e., natomiast najstarszą (Ic) od 24 do 25 tysięcy lat p.n.e. Zatem zachowały się tutaj pozostałości lokalnej sekwencji kultury graweckiej w okresie od 19 do 25 tysięcy lat temu. Nawiązując do jednej z ostatnich periodyzacji kultury graweckiej (Noiret, Engesser, Otte 1998), odkryte w Haliczu osadnictwo, możemy zaliczyć do III, IV i V stadium rozwoju środkowo- i wschodnioeuropejskiej kultury graweckiej. Natomiast w innym schemacie chronologiczno-kulturowym dotyczącym Naddniestrza (Djindjan, Koslowski, Otte 1999, ryc. 211) Halicz należy umieścić w III stadium rozwoju grawetienu na tym obszarze. Na tle grawetienu naddniestrzańskiego stanowisko w Haliczu wykazuje jednak pewną specyfikę zarówno gospodarczą (specjalizacja w polowaniach na 
mamuty), jak i typologiczną (znacząca obecność mikrotylczaków), co zbliża je do środkowoeuropejskiego pawlovienu, świadcząc być może o bliskich koneksjach między tymi dwoma obszarami.

\section{Podsumowanie}

Należy podkreślić, że Halicz I jest przykładem wschodniograweckiego osadnictwa o środkowoeuropejskich koneksjach, z pozostałościami trzech faz zasiedlenia między 19 a 25 tysięcy lat p.n.e. Dotychczasowe badania wykopaliskowe odsłoniły zaledwie część stanowiska, które z uwagi na swoje walory powinno być badane w przyszłości.

Tabela 5. Halicz I, Ukraina. Wyniki analiz uranowo-torowych przy zastosowaniu modeli wczesnej (EU) i liniowej (LU)*

\begin{tabular}{|l|c|c|}
\hline \multicolumn{1}{|c|}{ Nazwa i nr próby } & $\begin{array}{c}\text { Wiek EU } \\
\text { (w tysiącach lat) }\end{array}$ & $\begin{array}{c}\text { Wiek LU } \\
\text { (w tysiącach lat) }\end{array}$ \\
\hline Halicz W 220 & $10,7 \pm 0,2$ & $22 \pm 4,0$ \\
\hline Halicz W 221 & $10,1 \pm 0,85$ & $22 \pm 4,0$ \\
\hline Halicz W 268 & $10,0 \pm 0,2$ & $20 \pm 1,0$ \\
\hline Halicz W 287 & $18,0 \pm 0,5$ & $37 \pm 2,0$ \\
\hline
\end{tabular}

*Analizy zostały wykonane w Instytucie Nauk Geologicznych PAN w Warszawie przez H. Herman i P. Gorkę.

\section{LITERATURA}

Aleksandrowicz W. P., Boguckyj O., Dmitruk R., Łanczont M.

2002 Malakofauna lessów Naddniestrza halickiego, [w:] Lessy i paleolit, s. 253-288.

Anikovič M.

1998 Dniepro-Donskaja istoriko-kulturnaja oblast ochotnikov na mamontov: ot ,, vostočnovo gravetta” ku ,, vostočnomu epigravettu”, [w:] Vostočnyj gravett, Moskva, s. 35-66.

1999 O migracjach w paleolite. Stratum plus, Petersburskij archeologičeskij vestnik, Sankt Petersburg-Kiszyniów-Odessa.

Bogucki A., Łanczont M.

2002 Stratygrafia lessów Naddniestrza halickiego, [w:] Lessy i paleolit, Kraków, s. 315-327. 
Borziak I. A.

1993 Les chasseurs de renne de Kosoioutsy, site paleolithiue tardif a plusieurs niveaux sur le Dniestr moyen (rapport preliminaire), L'Anthropologie, t. 97, nr 2/3, s. 331-336.

1998 Gravett Podniestrovija i jevo svjazy s, ,jedinstvom Willendorf-Pavlov-Kostionki”, [w:] Vostočnyj gravett, Moskva, s. 135-141.

Borziak I. A., Koulakovska L.

1998 Grawet Podnistrovija. Zagalnyj ogljad, Archeologia, nr 4, s. 55-64.

Chirica V.

1989 The Gravettian in the east of the Romanian Carpathians, Iassy.

Cyrek K., Łanczont M., Sudoł M., Sytnyk O.

2005 Graweckie stanowisko w Haliczu na Ukrainie. Wyniki dotychczasowych badań, Rocznik Przemyski, t. 41, z. 2, Archeologia, s. 17-28.

Cyrek K., Łanczont M., Sytnyk O., Wrzesińska A.

2002 Górnopaleolityczne obozowisko towców mamutów nad środkowym Dniestrem (wyniki badań w latach 2000-2001), [w:] Starsza i środkowa epoka kamienia w Karpatach Polskich, red. J. Gancarski, Krosno, s. $97-109$.

Cyrek K., Sytnyk A.

2002 Paleolit Naddniestrza Halickiego, [w:] Lessy i paleolit, s. 293-314.

Czernysz A. P.

1959 Paleolit środkowego Naddniestrza, Moskwa.

1961 Paleolityčna stojanka Molodova V, Kijów.

1987 Mnogoslojnaja paleolitičeskaja stojanka Molodova V, Moskva.

Damblonn F., Haesaerts P., Borziak I., Plicht van der J.

1997 Climatic events and upper Palaeolithic chronology in the Dniester basin: new radiocarbon results from Cosautsi, Prehistoire Europeene, nr 12, s. 1-10.

Djindjan F., Koslowski J., Otte M.

1999 Le paleolithique superieur en Europe, Paris.

Escutenaire C., Kozłowski J. K., Sytlivy V., Sobczyk K.

1999 Les chasseurs de mammouths de la vallée de la Vistule. Kraków-Spadzista $B$, un site gravettien amas d'ossements de mommouths, Bruxelles.

Fedorowicz S.

2006 Metodyczne aspekty luminescencyjnego oznaczania wieku osadów neoplejstoceńskich Europy Środkowej, Gdańsk.

Grigoriev G. P.

1970 Verchnyj paleolit. Kamennyj vek na teritorii CCCP, Moskva.

Grigorieva G. W., Klapčuk M. N.

1981 Pozdnepaleolitičeskaja stojanka Mežygircy I w Ivano-Frankovskoj oblasti, Kratkije Soobščenija Instytuta Archeologii AN CCCP, t. 165, s. 58-63.

Haesaerts P., Borziak I., Chirica V., Damlon F., Koulakovska L.

2004 Cadre stratigraphique et chronologie du gravettien en Europe Centrale, [w:] The Gravettian along the Danube. Proceedings of the Mikulov 
conference 20.-21. November 2002, Dolní Věstonice Studies, t. 11, red. J. Svoboda, L. Sedláčková, Brno, s. 33-56.

Hronada J., Kozłowski J. K.

1995 Complex of upper palaeolithic sites near Moravany, Western Slovakia, t. 1, 2, Kraków.

Klima B.

1995 Dolní Věstonice II. Ein Mammutjägerrastplatz und seine Bestattungen, Dolní Věstonice Studies, t. 3, ERAUL 73, Liège.

Komar M.

2002 Analiza pyłkowa górnoplejstoceńskich lessów i gleb kopalnych stanowisk Yezupil i Halyč sites, [w:] Lessy i paleolit, s. 245-251.

Kulakovska L., Otte M.

1999 Mejigirzi, Préhistoire Europeenne, t. 13, s. 149-166.

Kozłowski J. K.

1992 Le Paléolithique des Carpates occidentals, Preistoria Alpina, t. 28/2, s. 126-133.

1998 The Gravettian in Central and Eastern Europe, Advances in World Archaeology, t. 5, s. 131-200.

2002 La Grande Planie de L'Europe avant le Tardiglaciaire, [w:] Préhistorie de la Grande Planie du Nord de L'Europe, Actes du Colloque Chaire Francqui interuniversitaire au titre étranger (Université de Liège, 26 juin 2001), ERAUL 99, Liège, s. 53-65.

2004 Świat przed rewolucja neolityczna, [w:] Wielka Historia Świata, t. 1, Kraków-Warszawa.

Kozłowski J. K., Kozłowski S. K.

1975 Pradzieje Europy od XL do IV tysiaclecia p.n.e., Warszawa.

1996 Le Paléolithique en Pologne, Grenoble.

Lessy i paleolit

2002 Lessy i paleolit Naddniestrza halickiego (Ukraina) [Loess and Palaeolithic of the Dniester River basin, Halyč region (Ukraine)], red. T. Madeyska, Studia Geologia Polonica, t. 119, Kraków.

Łanczont M., Boguckyj A., Kravčuk J., Yacyšyn A.

2002 Budowa geologiczna i środowisko przyrodnicze Naddniestrza Halickiego, [w:] Lessy i paleolit, s. 17-26.

Łanczont M., Poręba A., Zuberek W., Żogała B., Boguckyj A.

2005 Geofizyczne rozpoznanie górnopaleolitycznego obozowiska towców mamutów w Haliczu nad Dniestrem (Ukraina), Rocznik Przemyski, t. 41, z. 2, Archeologia, s. 3-15.

Noiret P., Engesser K., Otte M.

1998 Proposition de révision des stades techno-typologiques du Gravettien oriental, [w: ${ }^{14} \mathrm{C}$ et Archéologie, Actes du $3^{e}$ Kongres international de Lyon (avril 1998), red. J. Evin i in., Mémoire de la Société préhistorique français, t. 26, Paris, s. 151-155. 
Otte M., Noiret P., Chirica V.

1996 Rythme évolutif du Gravettien oriental, [w:] The Upper Palaeolithic. XIII International Congress of Prehistoric and Protohistoric Sciences Forli - Italia, red. A. Montet-White, A. Palma di Cesnola, K. Valoch, Colloquium XII, L'origin du Gravettien, Forli, s. 213-226.

Rogaczev A. N., Anikovič M. W.

1984 Pozdnyj paleolit Russkoj i Krima, [w:] Paleolit CCCP, red. P. I. Borisovskij, Moskva, s. 162-271.

Soffer O.

1993 Upper Paleolithic of the Central Russian Plan, New York.

Sobczyk K.

1995 Osadnictwo wschodniograweckie $w$ dolinie Wisty pod Krakowem, Kraków.

Svoboda J.

1994 Pavlov. Excavations 1952-1953, ERAUL 66, Liège.

Sytnyk O., Bogucki A., Łanczont M.

1999 Stanowisko górnopaleolityczne Halicz I, Materiały i Sprawozdania

Rzeszowskiego Ośrodka Archeologicznego, t. 20, s. 15-21.

Sytnyk O., Cyrek K., Bogucki A., Łanczont M.

2004 Paleolityczna stojanka Galicz I: Archeologia i geochronologia, [w:]

Problemy geomorfologii i paleografii Ukrainskich Karpat i terytoriów przyległych, Lwów, s. 215-237.

Sytnyk O., Cyrek K., Koropetskyi R., Wrzesińska A.

2005 Gravecka pamjatka Galycz I, Materialy i dosliždenija z archeologii Prikarpatija i Volynia, t. 9, s. 32-89.

Wojtal P.

2002 Zwierzęce szczątki kostne ze stanowiska Halyč, [w:] Lessy i paleolit, s. 291-292.

Wojtal P., Cyrek K., Sytnyk O.

2001 The new Upper Palaeolithic mammoth site at Halich (Ukraine), Acta Zoologica Cracoviensia, t. 44, s. 137-142.

\section{GRAVETTIAN SITE IN HALYCH (UKRAINE). RESULTS OF POLISH -UKRAINIAN ARCHEOLOGICAL SURVEY}

\section{Summary}

The Halych site is located on a cape of a high $\left(4^{\text {th }}\right)$ terrace on the right bank of Dniester River (fig. 3). During the survey, the Polish-Ukrainian expedition explored $340 \mathrm{~m}^{2}$. It is a non-defined closely fragment of a site largely destroyed by industrial exploitation of loess for the local brick plant (fig. 2, 3).

The relics of Paleolithic settlement appeared on 3 levels, at a depth of 200-230 $\mathrm{cm}$ from the surface. They constituted $1^{\text {st }}$ cultural stratum in the lower part of the 
Rivne type fossil soil (fig. 5, 6), created during warming and humidizing of the climate, related to the Lascaux interstadial in Western Europe.

The oldest of the discovered levels (Ic) has remained in a form of gray spots, single bones and dispersed flint products (365 specimens). The middle settlement level (Ib) was best preserved and included the largest number of finds. It included the hearth no 2, flint products grouped around it (2132 specimens) and a concentration of more than 800 bones, almost exclusively mammoth ones (fig. 13). The youngest settlement level (Ia) has remained in a form of hearth No 1, concentration of flint objects (2199 specimens) and dispersed, single bones (fig. 14).

The inventory from Halych shows close typological links both to the Dniester Molodova culture sets (for instance Molodova V, ex. VII and VIII and Mežygircy I), being a result of spreading of Gravette tradition from Western to Eastern Subcarpathian after $25 \mathrm{kyr}$. As a result of this process Molodova culture appeared in the area of middle and upper Dniester River. Also typological similarities of mid-European Pavloviene (Pavlov, Dolní Věstonice), should be noted.

Considering the radiocarbon and thermoluminescence dating it can be assumed, that the upper cultural stratum from Halych has three phases, and the youngest settlement phase (Ia), should be dated for the period between $19^{\text {th }}$ and $21^{\text {st }}$ millennium BC., the middle phase $(\mathrm{Ib})$, between $23^{\text {rd }}$ and $24^{\text {th }}$ millennium $\mathrm{BC}$, while the oldest (Ic), from $24^{\text {th }}$ to 25000 years BC.

Thus what remains, are relics of a local sequence of Gravettian culture, from the period between 19 to 25000 years ago. Upper Paleolithic settlement process had three phases there, and the youngest settlement phase can be dated for 19 and 21, 23 and 24 thousand years $\mathrm{BC}$ while the oldest for 24 to 25 thousand years BC.

Translated by Agata i Bogustaw Marciniakowie 
